بررسى تأثير شاخصهاى بيوند از دور بر توليد خالص اوليه (NPP) در دامنه شمالى البرز

سيد مرتضى عر اقى شهرى'، سعيد سلطانى '، مصطفى تركش' و سعيد يورمنافى

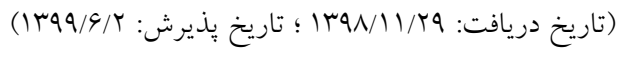

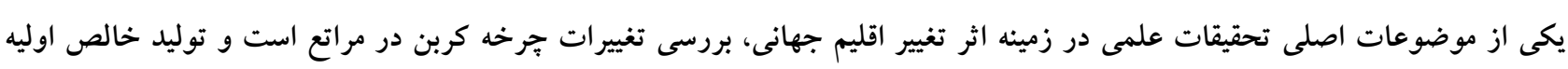

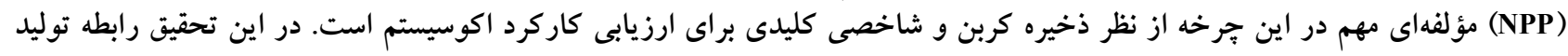

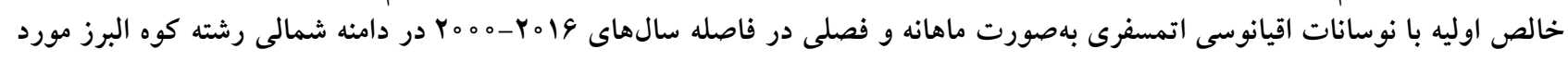

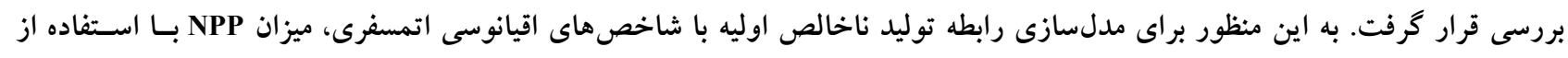

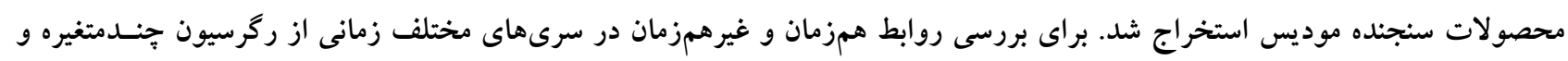

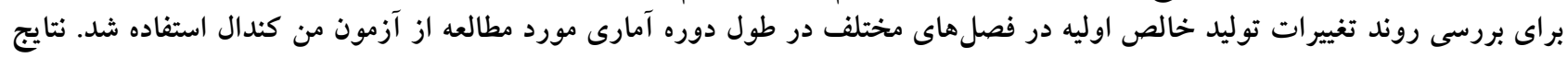

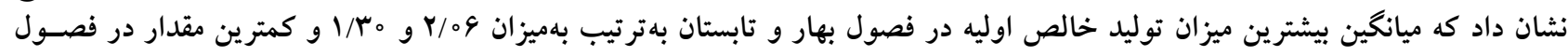

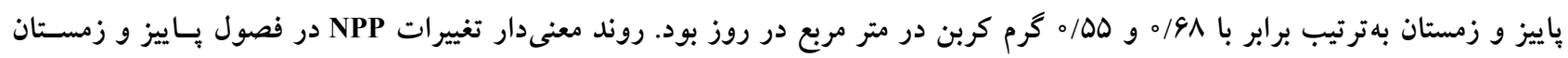

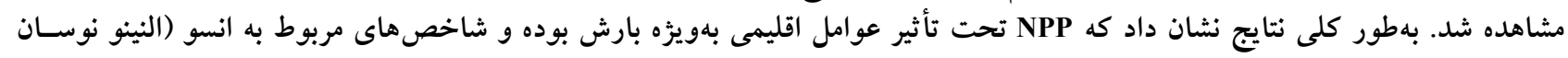

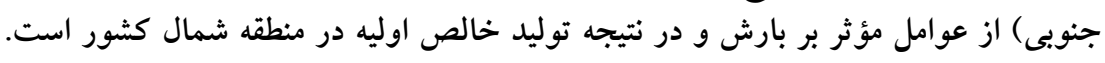

وازههاى كليدى: نوسانات اقيانوسى اتمسفرى، رگرسيون جندمتغيره، انسو، آناليز روند، من-كندال، سنجش از دور

ا. ا. كروه مرتع و آبخيزدارى، دانشكده منابع طبيعى، دانشكاه صنعتى اصفهان، اصفهان.

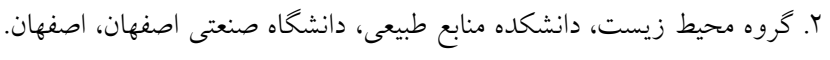

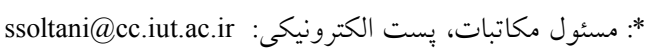


رطوبت و تابش فعال فتوسنتزى است كـهـ ايـن عوامـل همـواره توزيع جغر افيايى و رشد كياهان را در سطح زمين كنترل مى كنند

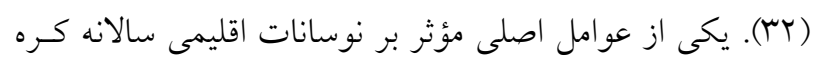

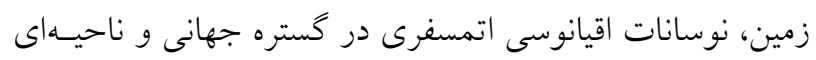

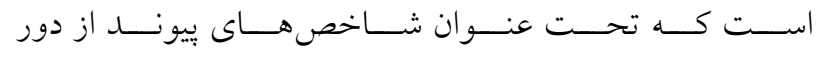
شناخته مسى شـوند و از مهـمتـرين (Teleconnection Indices)

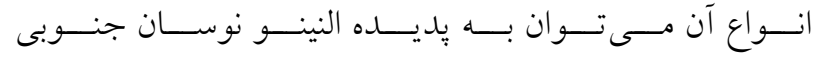
SOI =Southern Oscillation Index) (NAO =North Atlantic Oscillation) و ونوســAO =Arctic Oscillation) اشاره كـــد. هـر كـدام از (MO =Mediterranean Oscillation) اين بديدهها اقليم بخشى از كره زمسين را تحـت كنتـرل دارنـــ.

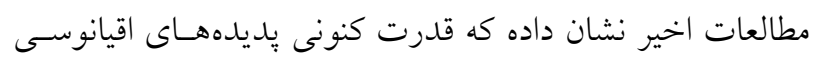

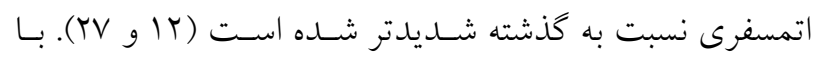

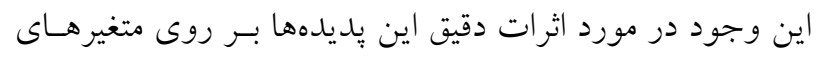
اقليمى اختلاف نظر وجود دارد (ه\&). مطالعات اخير نشـان داده

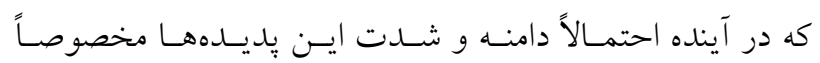
(Elnino Southern Oscillation) ENSO 94). يكى از موضوعاتى كه در دهلهاى اخير براى تبيسين رفتـار

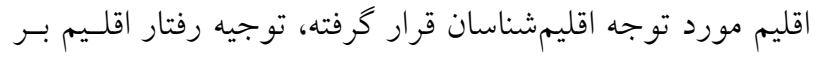
اسـاس سـازوكارهاى بيونــــ از راه دور اسـت. بيونــــ از دور در

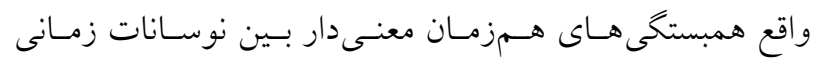

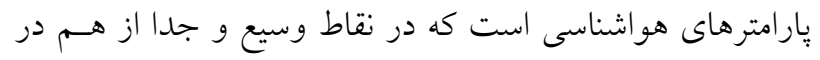

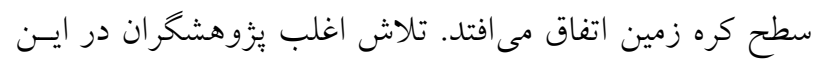

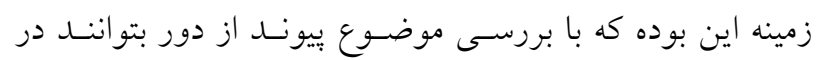

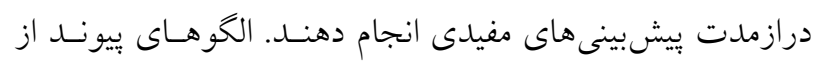

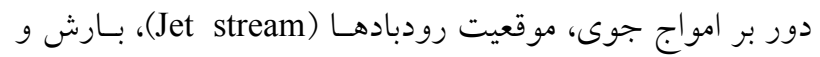

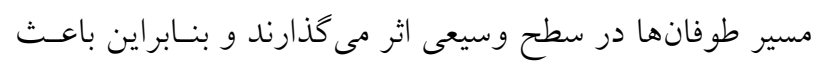

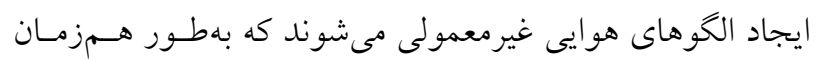

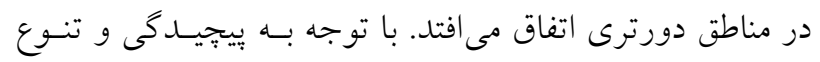

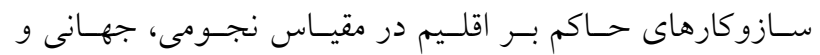
منطقهاى، بهويزه ساز كارىهاى حاكم بر تغييرات سال به سال و

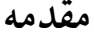

آَكاهى از مقدار كربن جهانى براى توسعه سياسـتهـيـى جهـت

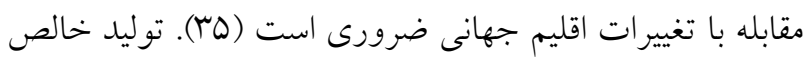

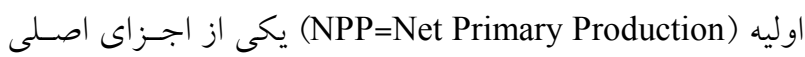

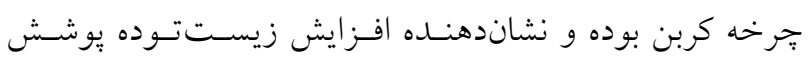

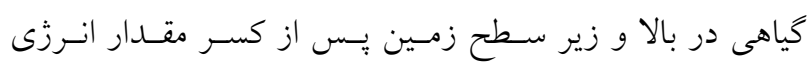

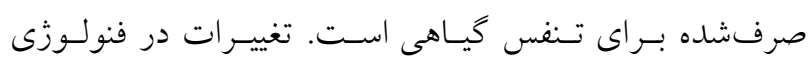

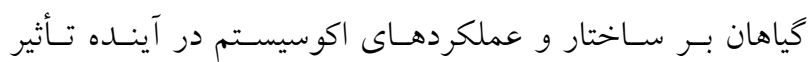

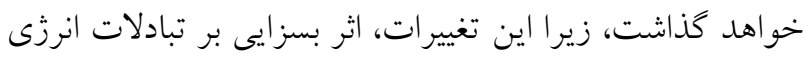

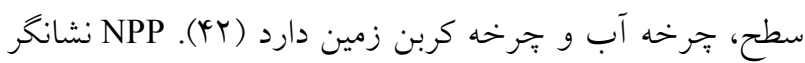
انباشت CO2 در اكوسيستمهاى زمينس بـوده و نقـش مهمى در

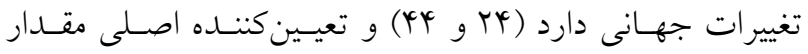
ذخيره كربن زمين و يكى از عوامل اصلى تنظيم كننده فرايندهاى

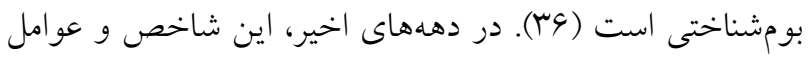

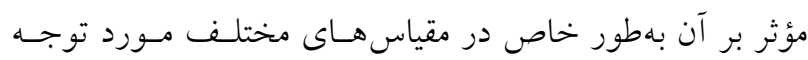

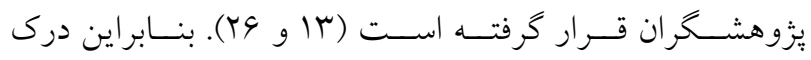

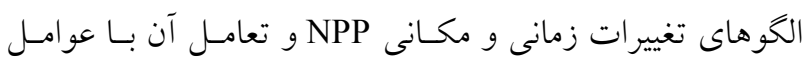

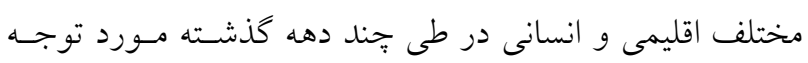
مطالعات مربوط به حوضه تغييرات جهانى بوده است. توجه بــه

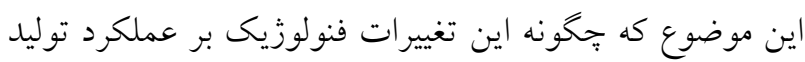

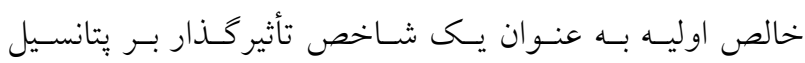
اكوسيستم براى ذخيره مو اد مغذى مـؤثر اسـت، رو بـهـ افـزايش

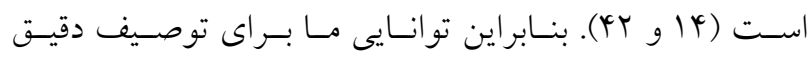
عملكرد NPP به تغييرات فنولوزيكى و همجنــين بـه درك مـا از

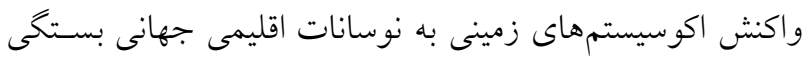

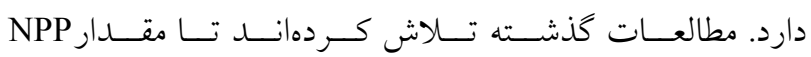
اكوسيستمهاى زمينى را تخمين بزنند و همجنين رياسخ آن را بـهـ

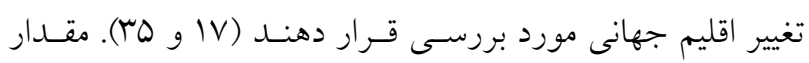

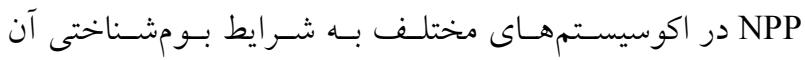

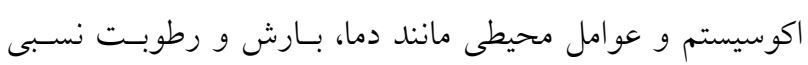

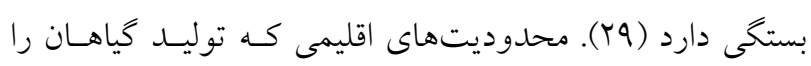

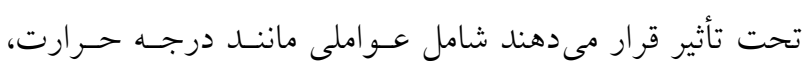




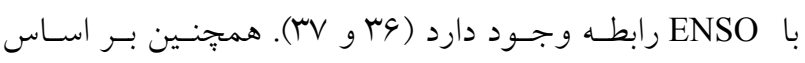

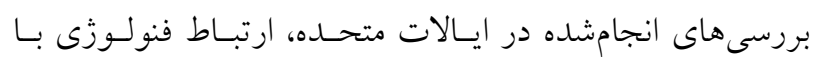

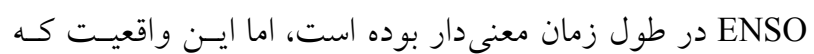

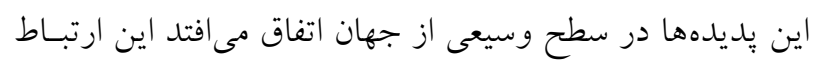

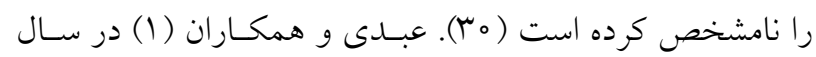

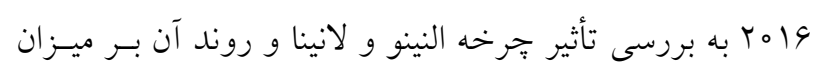

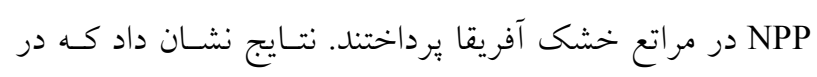

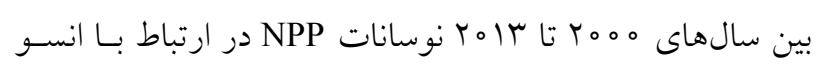
در سراسر خشكى هاى منطقه جنوب صحراى آفريقا تأثير زيادى

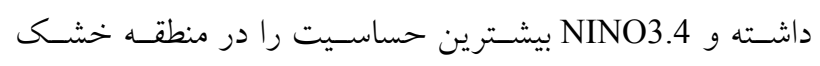

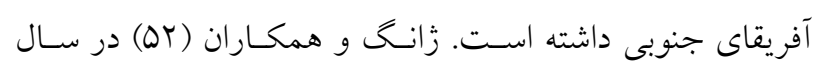

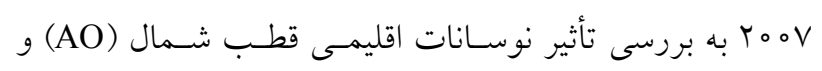

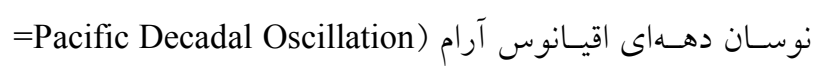

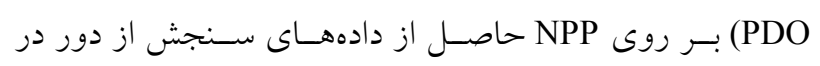

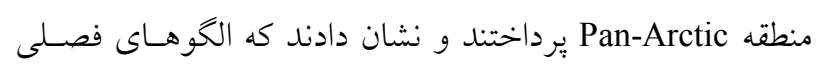

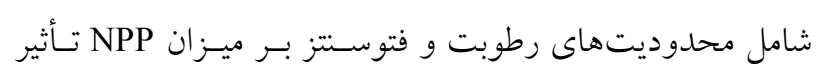
دارد. الكوى نوسان قطب شمال (AO) در اوايل بهار (فوريسه تـا

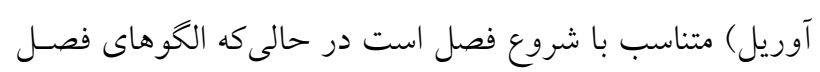

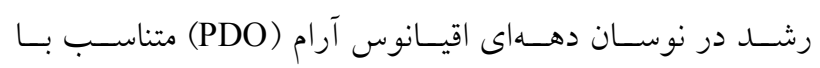
محدوديت هاى رطوبت در دسترس بــراى توليــ NPP هسـتند.

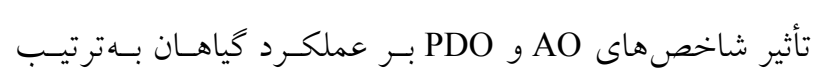

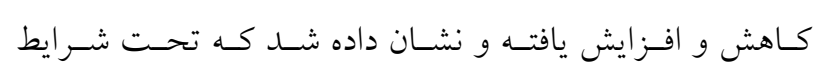

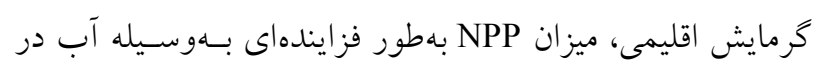
دسترس محدود مىشود. هاشسيموتو و همكـاران (Tسان) در سـال أن Yoof

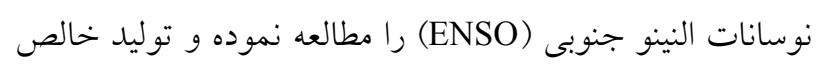

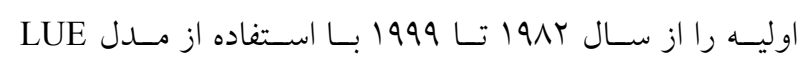
براسـاس يارامترهـاى تـاج يوشـش (Light Use Efficiency)

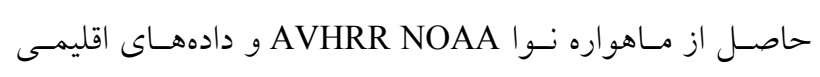

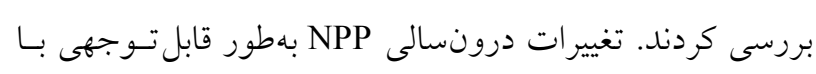

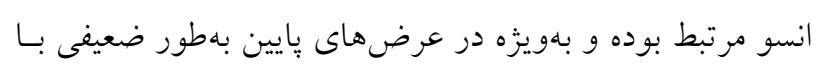

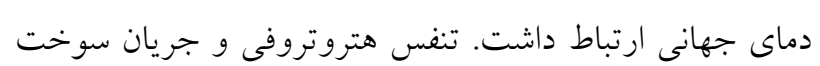

دهه به دهه آن، لزوم تحقيق در مورد فرآيندهاى اثركذار بر ايسن

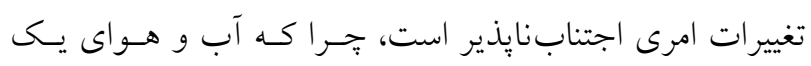

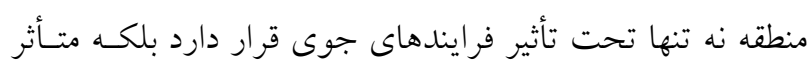

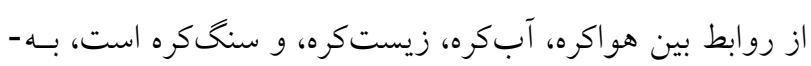

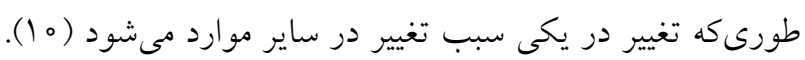

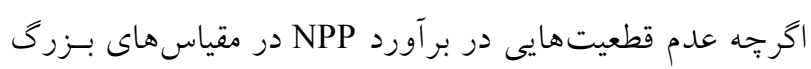

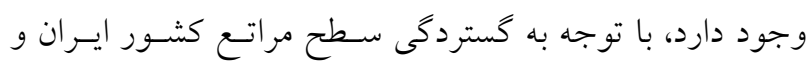

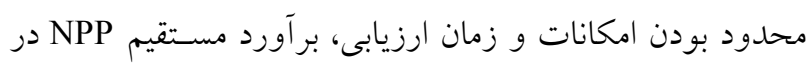

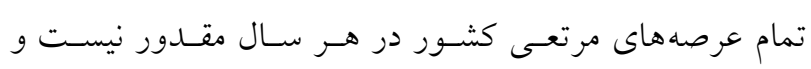

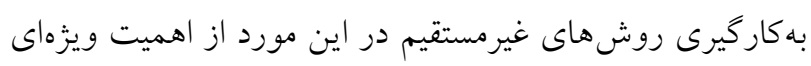
برخوردار است. يكى از روش هاى غيرمستقيم بهمنظـور بــرآورد

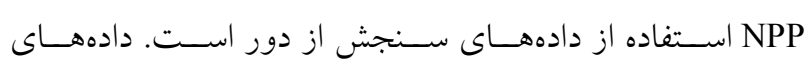

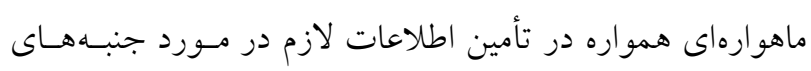

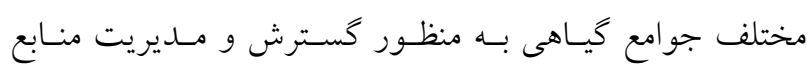

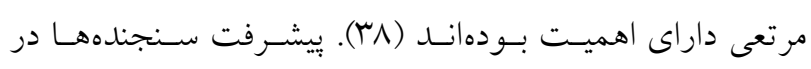
سنجش از دور (RS =Remote Sensing)، تو انايى مطالعه دقيـق داريق

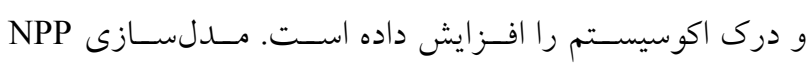
براساس دادههاى سنجش از دور بـهـ بررسى توليــ كياهـان در

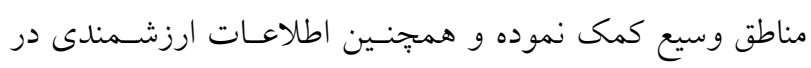

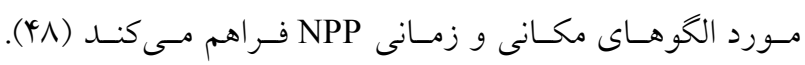

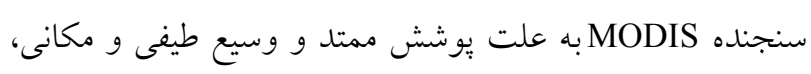

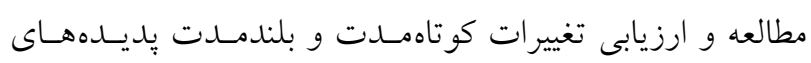

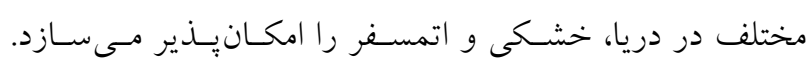

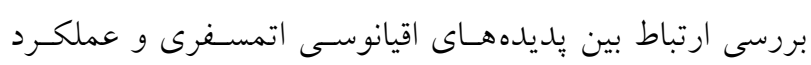
يوشش گياهى در بيشبينى توليـدات كيـاهى و مــديريت منـابع

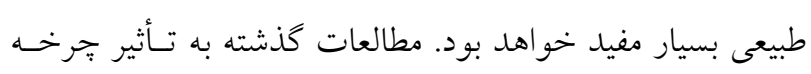
ENSO

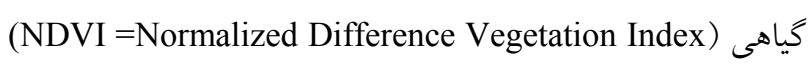

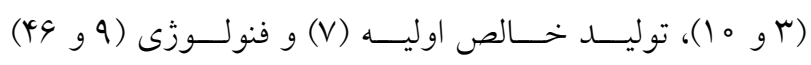

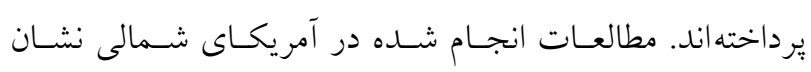

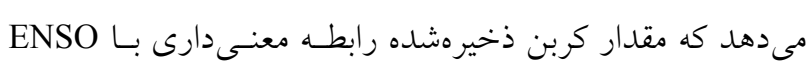

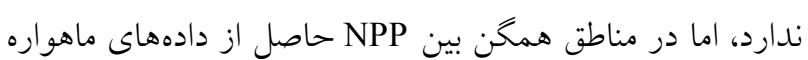




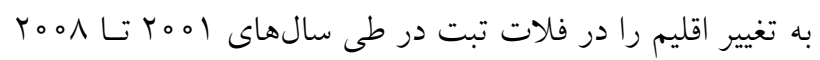

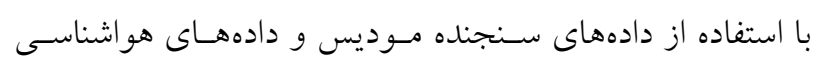

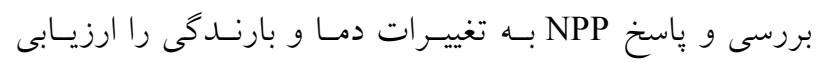
كردند. نتايج نشان داد كه بهدليل اثرات تركيبى تغييرات بارندگى

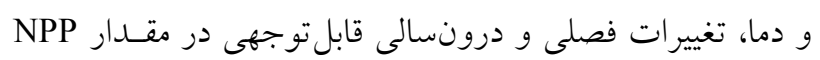
وجود دارد، به گونهاى كه افـزايش دمـاى متوسـط سـالانه تـأثير مثبت زيادى بر روى NPP داشـته و تغييـرات بارنـدكى سـالانه

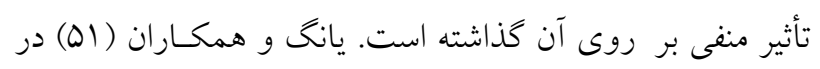

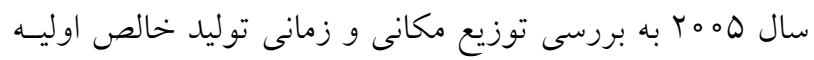
در امتداد ترانسكت شمال شرقى جهـين و واكـش آن بـهـ تغييـر

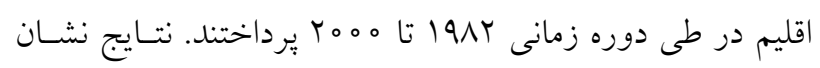

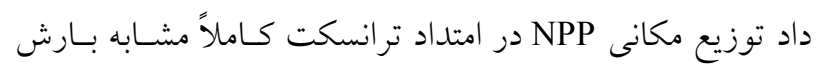
است، تغييرات درونسالى NPP در هر سال تحت تأثير تغييرات آب و هواى محلمى منطقه قرار مى گيرد، NPP اغلب در ماههـاى مى و سيتامبر تجمع يافته، فصـل تابسـتان 90/9 درصــ از كـل

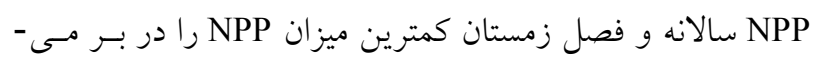
كيرد، و در فاصله دهـه م191 تـا 1991 مقـدار NPP بـه ميـزان

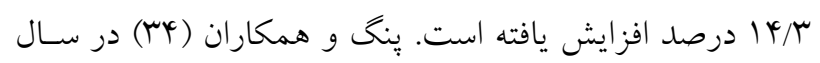

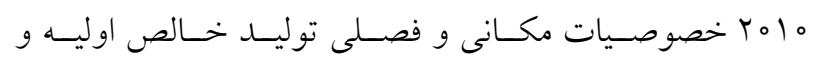
متغيرهاى اقليمى را در جنوب شرقى جين با استفاده از دادههاى سنجنده موديس بررسى كردند. نتايج حاكى از نقش تـأخيرى و مداوم تغييرات اقليمى در تغييرات فصلى NPP بود. اين مطالعسه با بررسى ويزگ گىهاى فصلى NPP و متغيرهاى اقليمى با استفاده از سيستم اطلاعات جغر افيايى (GIS) در سطح بيكسـل توسـعه

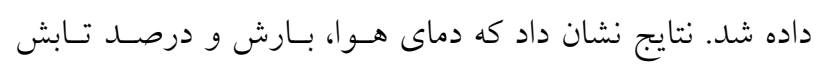
آفتاب بهطور معنى دارى بر تغييـرات فصسلى NPP اثـر كذاشـته

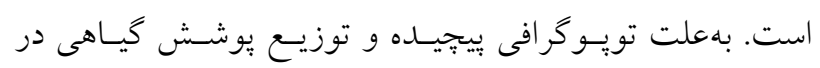

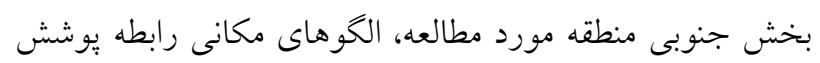

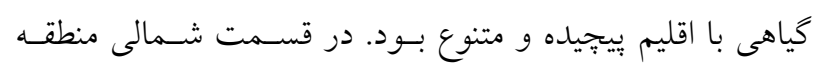

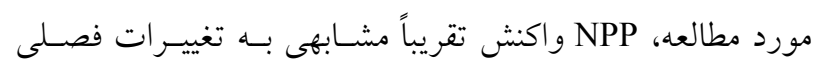
دماى هوا داشت. اثرات تغييرات فصلى بارش و تابش خورشـيد بر روى محصول غلات نسبت به ساير توليـدات معـرف NPP،
كربنى بهشدت با دماى جهانى ارتباط داشت و وابستـى تـنفس هتروتروفى و جريان سوخت كربنى به تغييريذيرى دماى سالانه تأييد شد و نشان داده شد كه تغييرات NPP تحت تأثير انسو بـر سرعت رشد $\mathrm{CO}_{2}$ در جو تأثير مى گذارد. باسـتوس و همكـاران

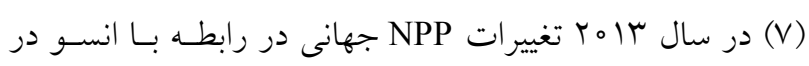

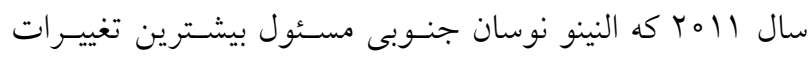
مشاهده شده در زمين بود و ناهنجارىهاى بـالاى NPP در ايسن

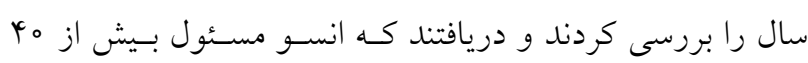
درصد تغييرات جهـانى NPP بـر اتـر واكـنش اكوسيستمهـــ نيمكره جنوبى بهويزه در مناطق گرمسيرى و نيمه كرمسيرى بوده

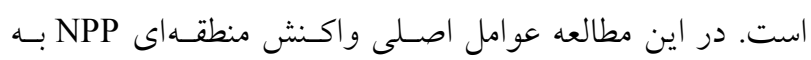
انسـو شـامل در دسـترس بــودن آب، كتــرل بـهوسـيله دمـا و

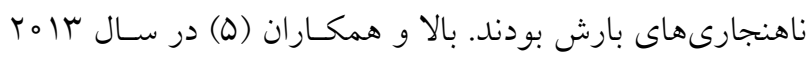
روند و تغييريذيرى NPP حاصل از دادههاى سنجنده AVHRR

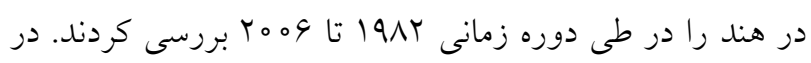
طى اين دوره يك روند افزايش شد. رگرسيون خطى جنامتغيره بين NPP با دما، بارش، غلظـت

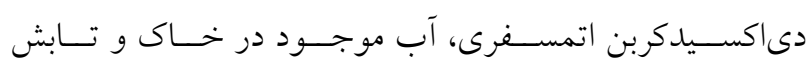
خورشيدى نشان داد كه اين روند افزايشسى تـا حسـدى ناشسى از

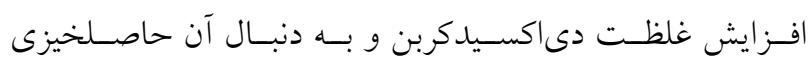
اكوسيستم ناشى از تثبيت CO2 بـوده اسـت. ملاحظـات انسـانى

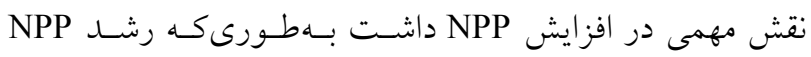
غيرجنخلى عمدتاً به دليل توسعه مناطق آبيـارى شــده و كـاربرد كود بود، در حالى كه NPP جنشلى متأثر از برنامسه كشـت و زرع

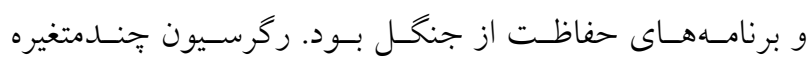

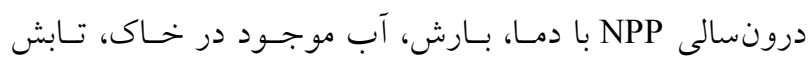

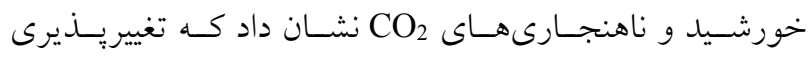
درونسالى NPP در درجه اول ناشى از تغييريذيرى بارش و دما است. ميانخين فعلى NPP يُ از وقوع جريان مونسون بيشترين مقدار و بيش از مونسون كمترين مقدار را داشت كه نشاندهنده اهميت رطوبت موجود در خاك براى رشـــ و افـزايش بوشـش

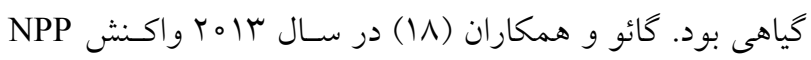




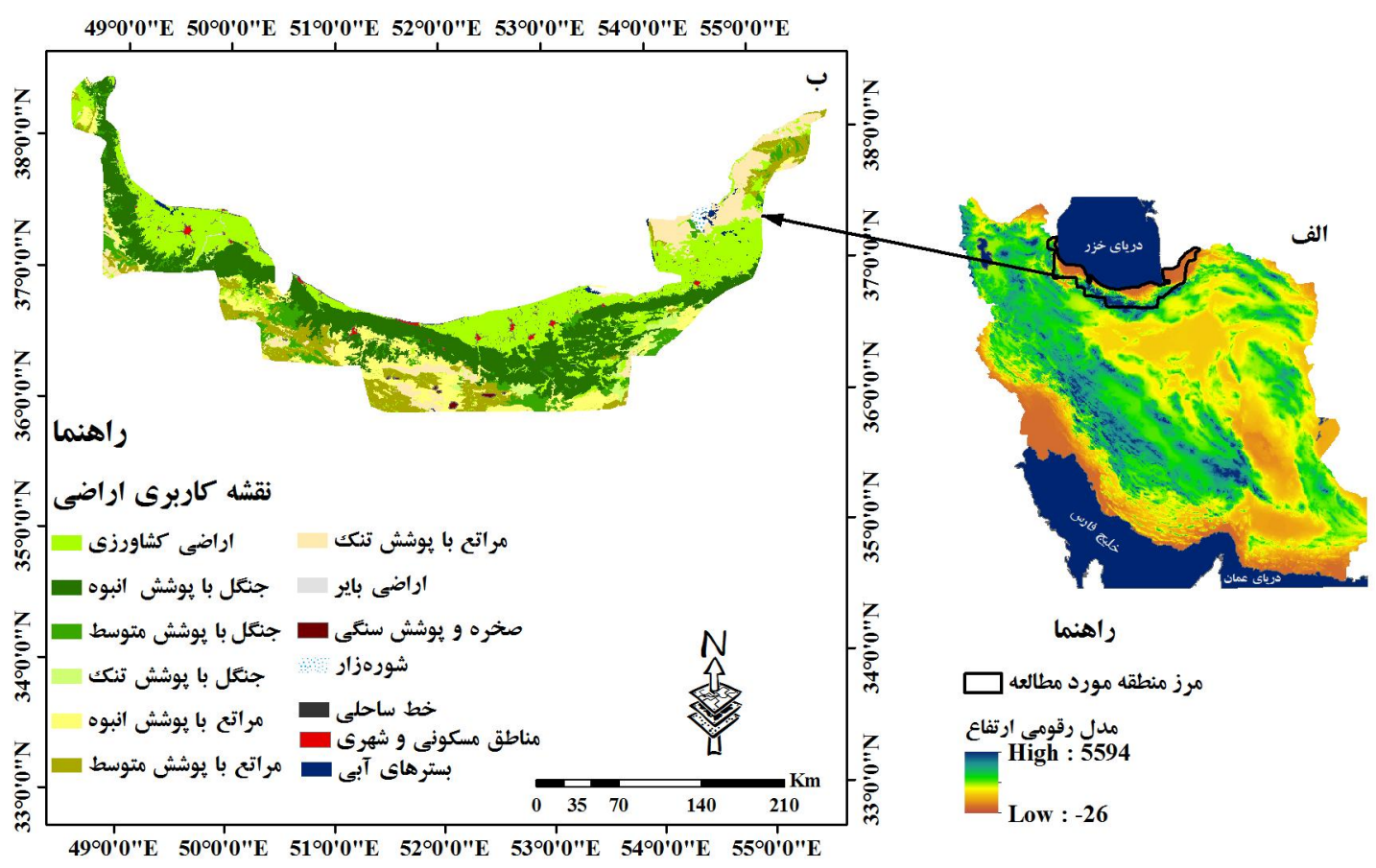

شكل 1. موقعيت منطقه مورد مطالعه در ايران (رنكى در نسخه الكترونيكى)

مديريتى، حفاظت و احيا هستند. از اينرو هـــف از ايـن تحقيـق بررسى ارتباط مقادير NPP و شاخص هاى اقيانوسى اتمسـفرى در هري

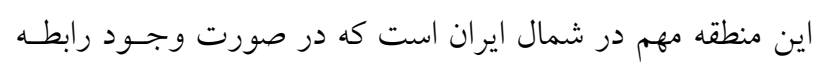

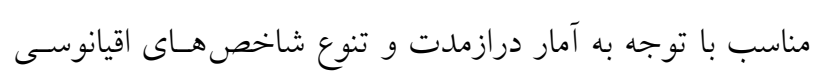

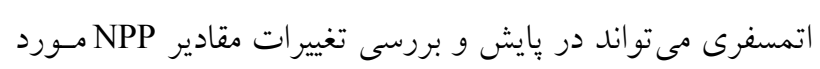

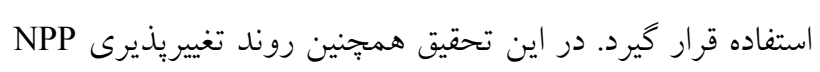

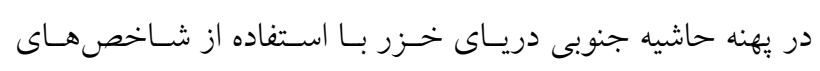
اقيانوسى اتمسفرى بررسى شد.

مواد و روشها منطقه مورد مطالعه

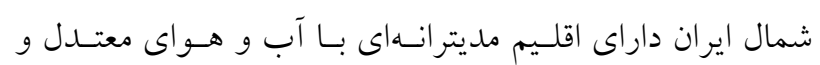

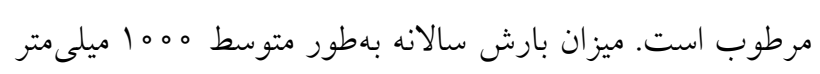

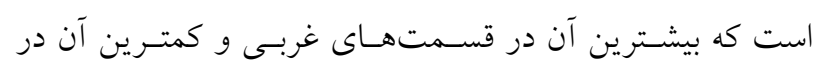

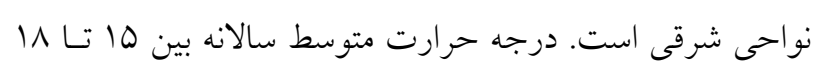

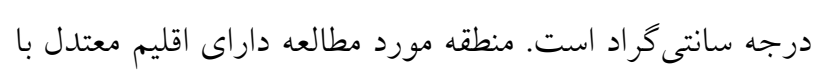

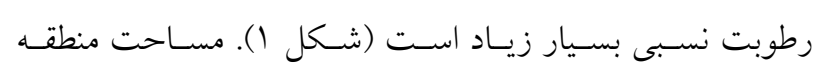

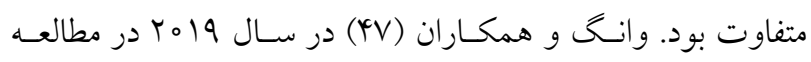

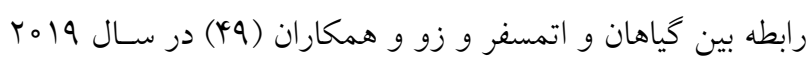

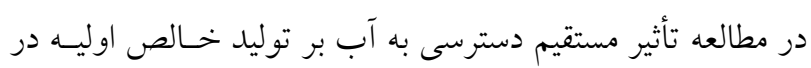
جانين بيان كردند كه عوامل اقليمى و تغييرات اقليمى، تـأثير بسـيار زيادى بر تغيير توليدات اكوسيستمهــاى زمينسى و مــديريت آنها

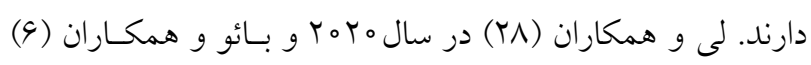
در همين سال در مطالعه فاكتورهاى مؤثر بر توليدات كياهى بيـان

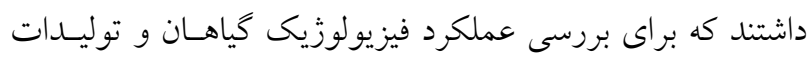
كياهى، تخمين تأثير عوامل اقليمى بر كياهان اهميت دارد.

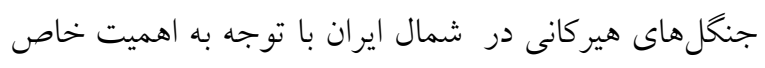

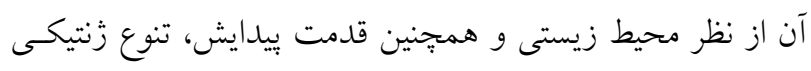

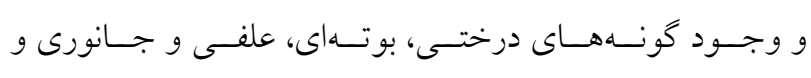
كاركردهاى بو مشناختى و بومكردى به عنوان يكى انهى از قديمى تسرين

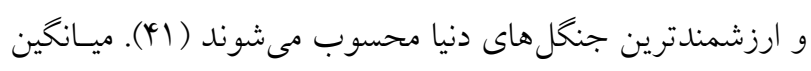

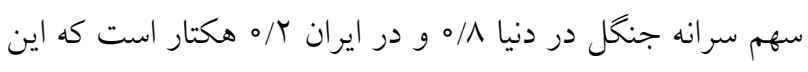

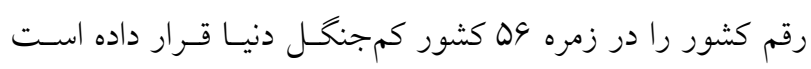

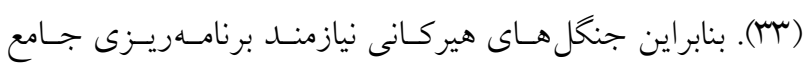


. آرام (NINO1.2، NINO3.4، NINO3 و NINO4) اس شاخص نوسان قطب شمال (AO) بر اسـاس ناهنجـارىهـاى فشار نقطهاى در قطب شمال و ناهنجارىهاى فشار عرضهاى

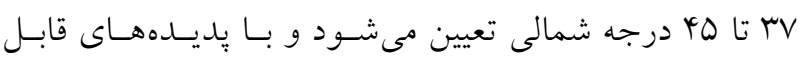
بيشبينى الكوهاى هواى مناطق دورتر مثـل ارويـا و آمريكـاى شمالى مرتبط است. قاسمى و خليلى (Yo) در بررسى تـأثير

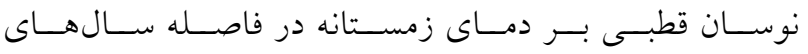
1981-Yooo - بيان كردند كه در بيشتر مناطق ايران دماى هواى زمستانه با شاخص AO همبستخى منفى داشته است. شـاخص نوسان قطب جنوب (AAO) يكسى از مهـم تـرين نوسـانهـاى اقيانوس -جو در عرض هاى بـالاى نيمكــره جنـوبى اسـت كـهـ بسيارى از الكوهاى هواشناسى را در عرضهاى ميانى و بالايى اين نيمكره بهشدت كنترل مى كند. شاخص نوسان جندادهـهاى اقيانوس اطلس (AMO) يك يديده اقيانوسى با مقياس زمـانى طولانى با تداوم بالا است. اين شاخص بر روى بارش و دماى

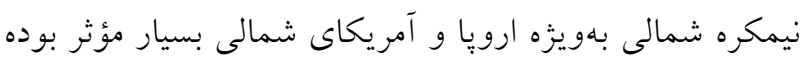
و ارتباط مسـتقيمى بـا شـدت و فراوانسى خشكسـالى در ايـن

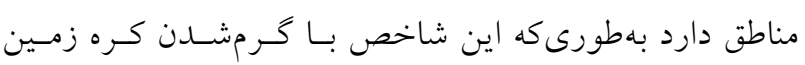
روند صعودى داشـته اسـت. شـاخص نوسـان اطلسس شـمالى يك نوسان بزرگمقياس در توده هوا است كه بيـانخر (NAO) حالت مهمى از تغييرات اقليمى از آمريكاى شمالى تا ارويـا و

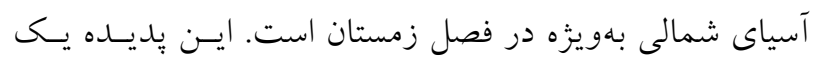

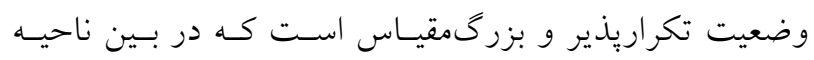
محدود به مركز برفشار استوايى و كمفشار قطبى رخ مى دهد و

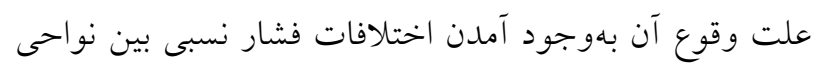
يرفشار استوايى و نـواحى قطبسى در اقيـانوس اطلـس شـمالى است. در واقع ميانكين دماى جند نقطه در محسدوده مشـخص محاسبه و سيس نرمـال شــه و بـهـصورت اسـتاندارد تبـديل مــى شــود. دزفــولى و همكــاران (هان ) در بررسـى ارتبــاط خشكسالى جنوب ايران بـا شـاخص هـاى SOI و NAO بيـان كردند كه بارندگى ياييز با اين دو شاخص همبسـتحى منفى و معنى دار دارد. شاخص نوسان مديترانـه غربسى (WMO) يـى
هكت AVIINV

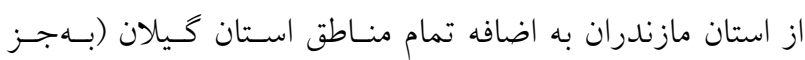
محدودهاى كو جكى در جنوب اين استان)، بخشـهاى زيـادى از استان كلستان (بهويزه مناطق شمالى، شمال شرقى، شمال غربسى و بخشهايى از جنوب غربى ايسن اسـتان) و بخـش كـوجكى در شمال شرق استان قزوين را در برمى گيرد. ميـانخين ارتفـاع ايسن يهنه رويشى سזه ا متر از سطح دريا است (TO). بر اساس شكل ا-ب حدود مب درصد منطقه مورد مطالعه را اراضى با بوشـش

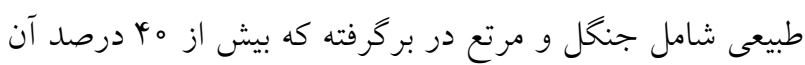

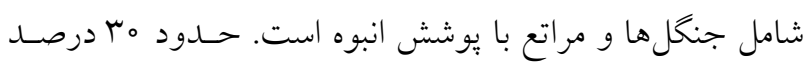
از سطح منطقه را نيز اراضى كشاورزى يوشانده است.

دادههاى مورد استفاده دادههاى سنجش از دور براى برآورد توليد خالص اوليـه در ايسن مطالعـه از محصـولات

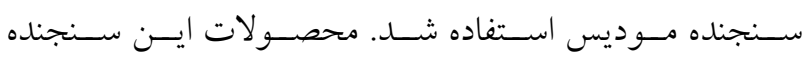
مجموعهاى از اطلاعات در مورد يوشـش گيـاهى را بـا قـدرت تفكيك مكانى و زمانى مناسب در اختيار كاربران قرار مسىدهـــ. به اين منظور، دادههاى NPP ماهانـه توليـدى ســنجنده مـوديس مربوط به منطقه مورد مطالعه در فاصله سالهـاى 19 ب00-Yoه از تارنماى https://neo.sci.gsfc.nasa.gov دانلود شد.

\section{دادههاى شاخص هاى اقيانوسى اتمسفرى}

دادههاى شاخص هاى اقيانوسى اتمسفرى منطقه مـورد مطالعـه

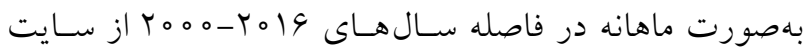
هو اشناسى اسـتر اليا (http:/www.bom.gov.au) دريافـت شـد. شاخص هاى مورد مطالعه در اين تحقيق شامل شاخص نوسان

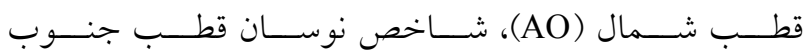
(AAO =Antarctic Oscillation)، شاخص نوسان جند دهداى ) اقيــانوس اطلــس (atlantic Multi-decadal Oscillation)

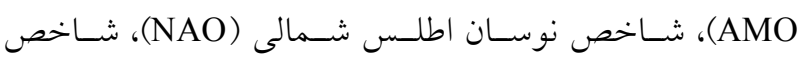

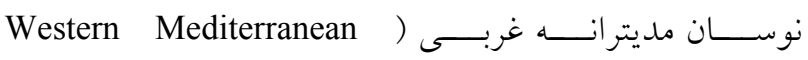
و و شاخص هاى نوسانات دمايى اقيانوس 
اينكه مقادير منفى نشاندهنده تجزيه و تنفس كياهى است، ايسن

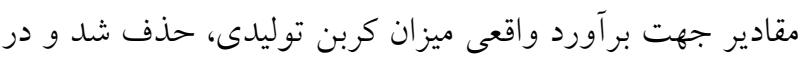
نتيجه، حداقل و حداكثر مقدار توليد خالص اوليسه، صـفر و 9/0

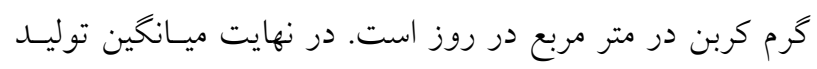

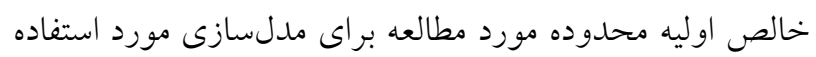

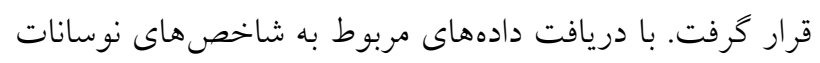

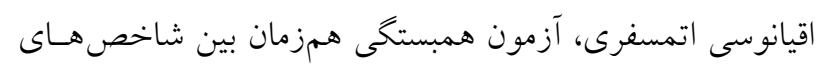

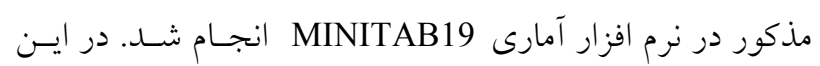

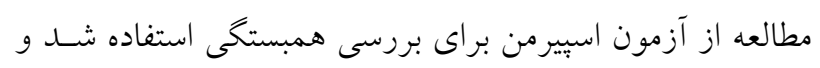

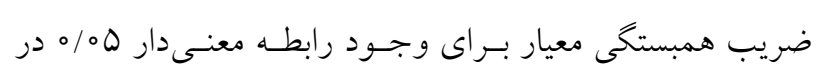

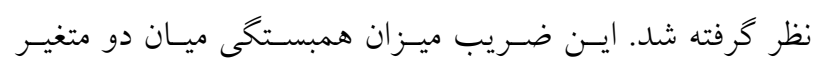

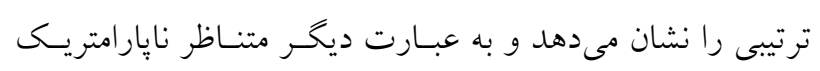

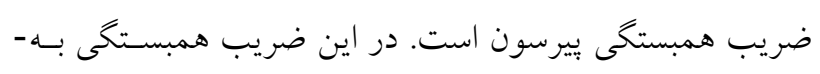

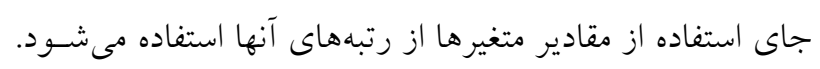

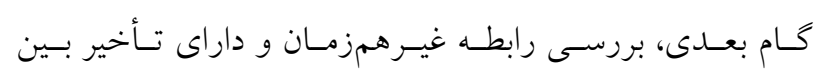

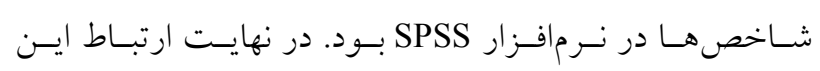

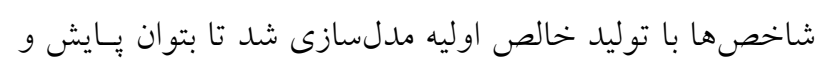

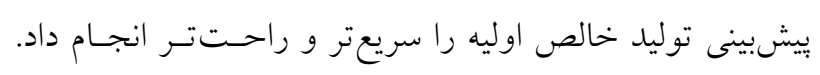

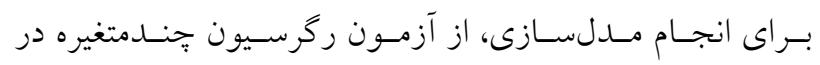

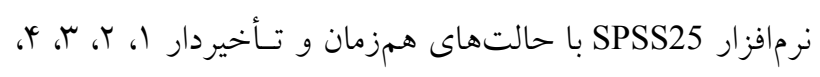

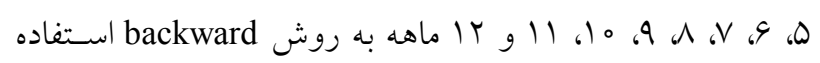

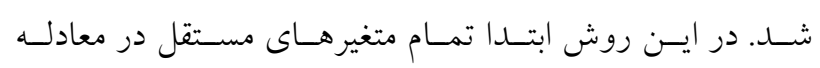

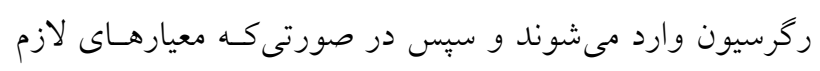

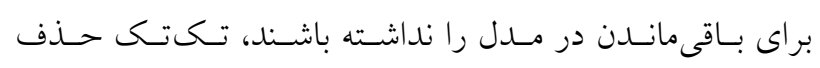

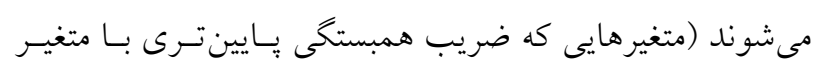

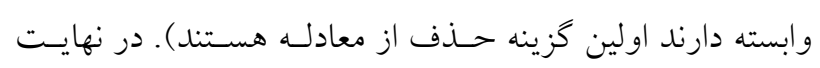

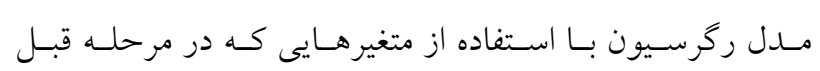

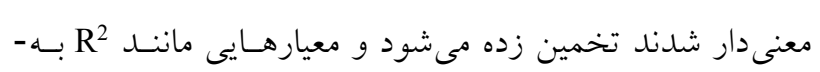

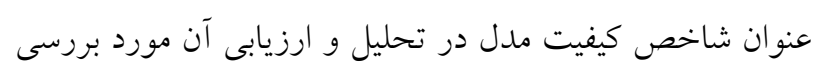

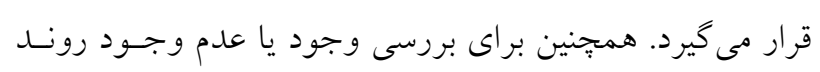

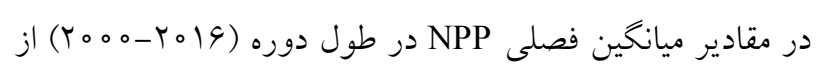
آزمون من كندال استفاده شد.
الكوى جديد ارتباط از دور منطقهاى است. اين نوسان تنهـا در

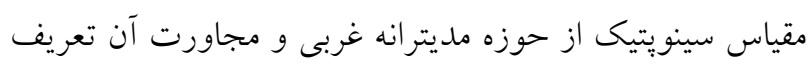

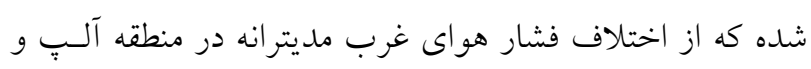

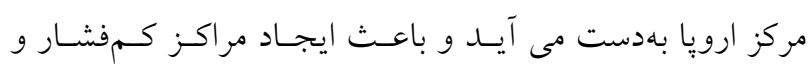

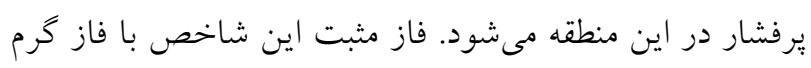

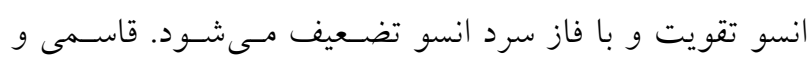

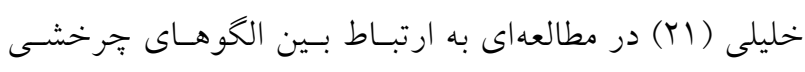

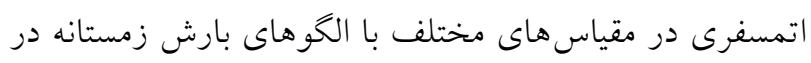

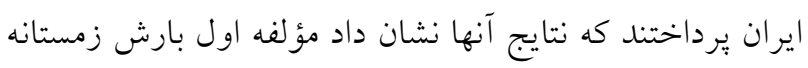

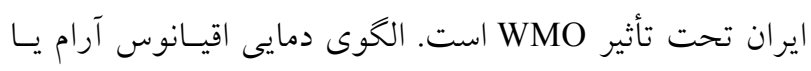

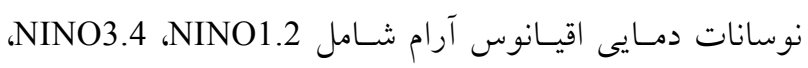

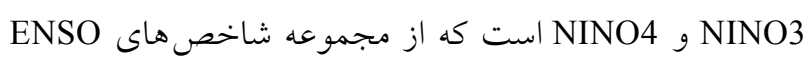

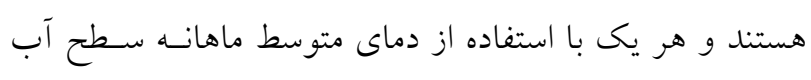

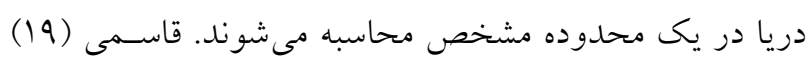

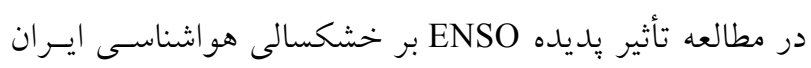

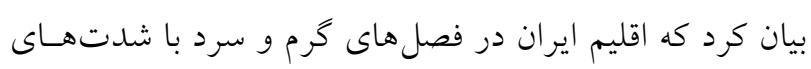
متفاوت تحت تأثير اين بديده قرار دارد.

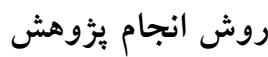

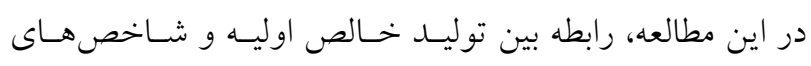

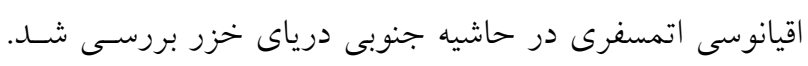

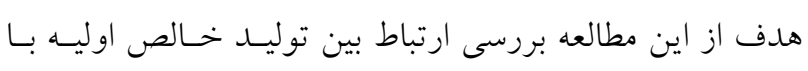

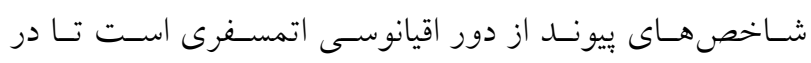

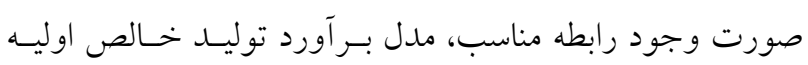

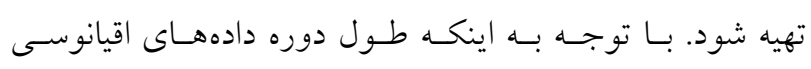
اتمسفرى مناسب بوده و به صورت رايخـان در تمـام دنيـا قابـل دسـترس اسـت در صـورت يـافتن معـادلات مناسـب، امكــان

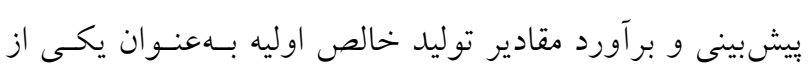

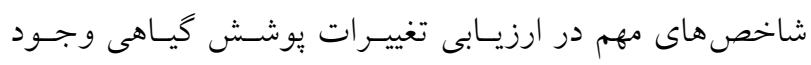

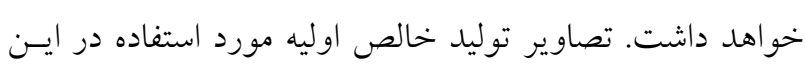

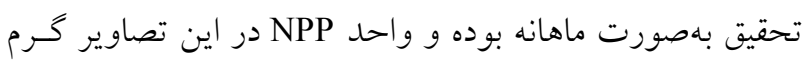

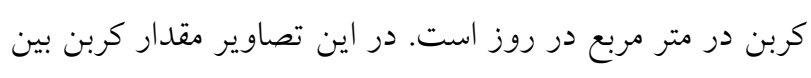

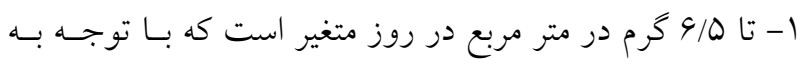


معنى دارى با شاخص هاى NINO1.2 زوئن، NINO1.2 مارس و

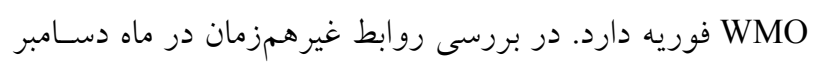

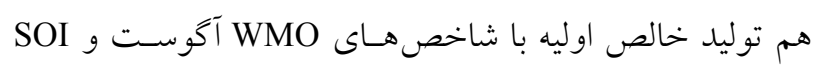

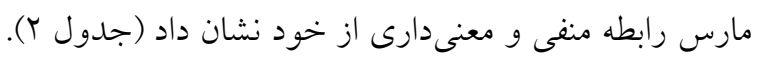

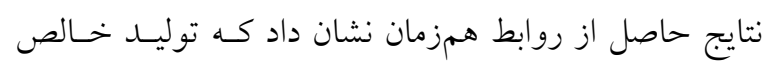

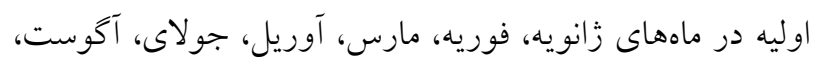

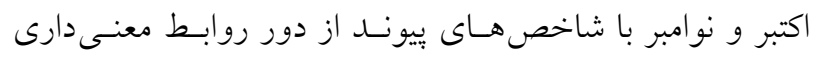

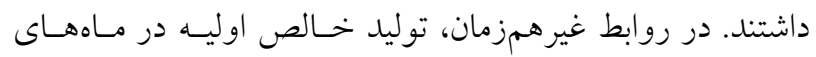

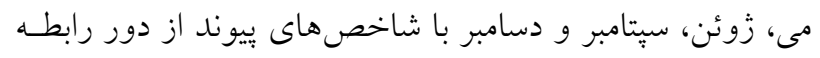

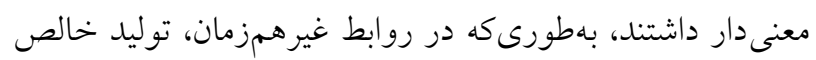

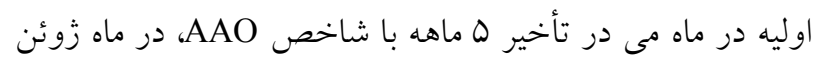

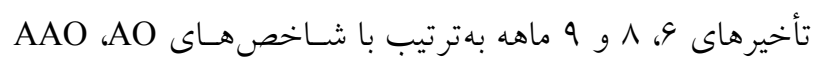

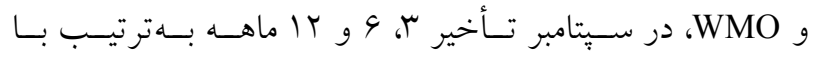
شـاخصهـاى NINO1.2 و WMO و در دسـامبر تـأخير ب و و 9 ماهه بهترتيب با شاخصهاى WMO و SOI روابط معنى دارى

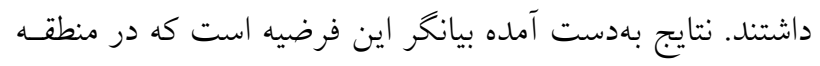

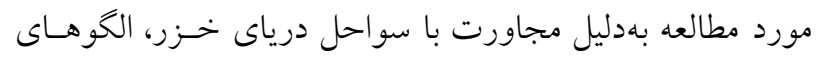

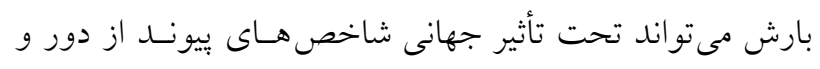

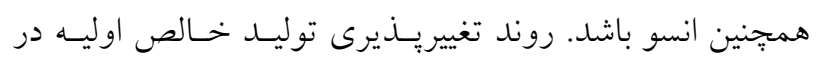
فصل بهار در طول دوره مورد مطالعه نشان داد كه كمترين ميزان

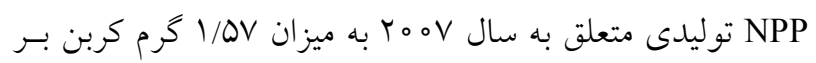

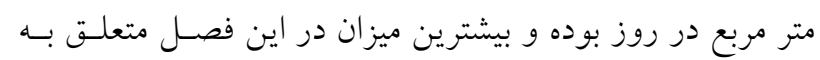

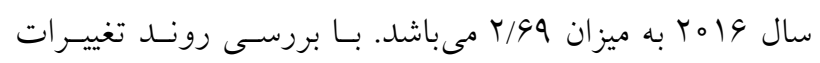

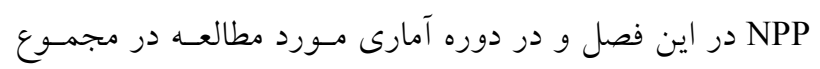

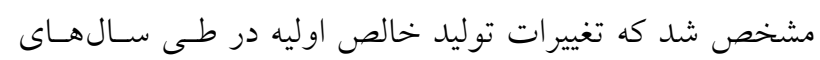

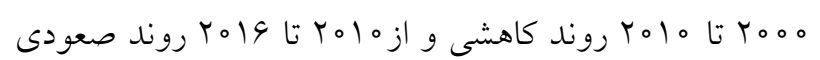

$$
\text { داشته است (شكل r) (Y). }
$$

در اين فصل شاخص NINO3.4 رابطه معنى دار و مثبـت بـا

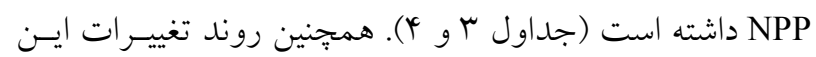

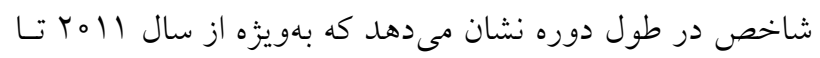

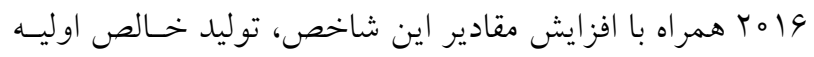

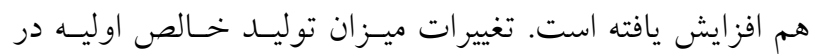

نتايج نشان داد كه در منطقه مورد مطالعه در ماه زانويـه، WMO

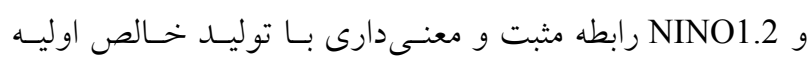

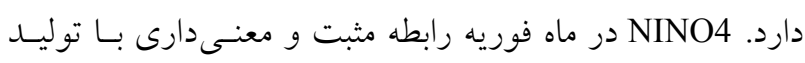

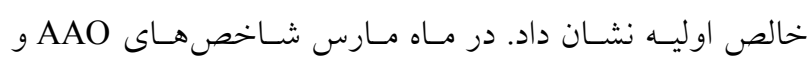

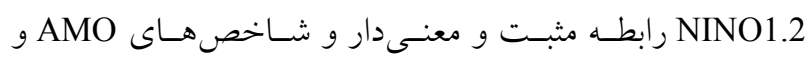

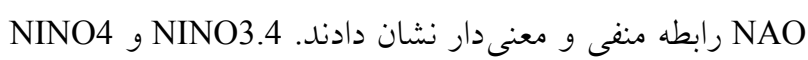

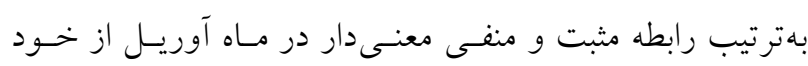

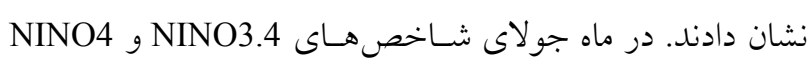
بهترتيب رابطه منفى و مثبت معنسى دار داشتند. SOI و NINO4

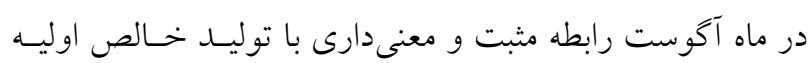

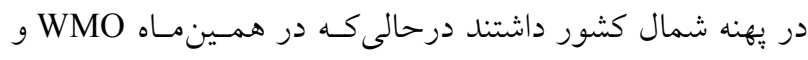

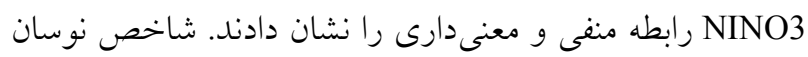
جنوبى (SOI) در ماه اكتبر رابطه منفسى و معنسى دارى بــا توليــ خالص اوليه نشان داد. در مـاه نـوامبر AMO و NINO3 رابطـهـ

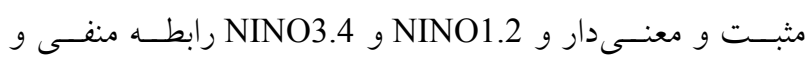
معنى دار با توليد خالص اوليه نشان دادند (جدول ()). تحليل رگرسيون با روابط غيرهمزمان

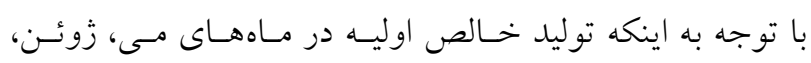

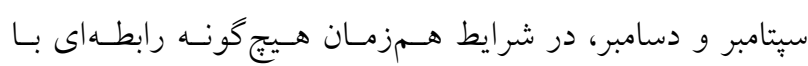

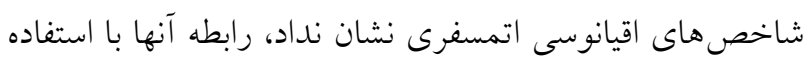

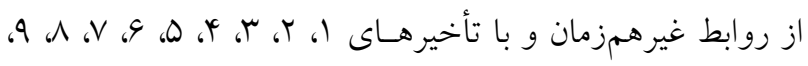

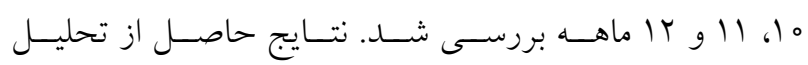

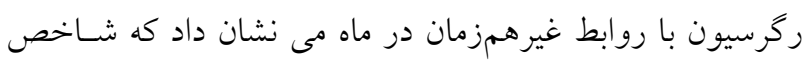

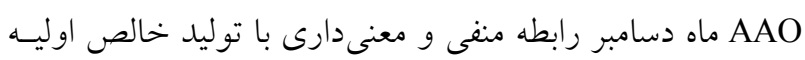

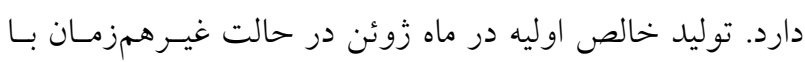
شـاخصهـاى AO دسـامبر و WMO ســتامبر رابطـه مثبـت و معنى دار و با شاخص AAO در ماه اكتبر رابطه منفى و معنسى دار

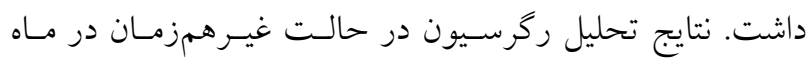
سبتامبر نشان داد كه توليد خالص اوليه در اين ماه رابطه مثبت و ورئر 
جدول ا. روابط رگرسيونى براى برآورد NPP در ماهاى مختلف در منطقه مورد مطالعه در روابط همزمان

\begin{tabular}{|c|c|c|}
\hline توليد خالص اوليه & $\mathrm{R}^{2}$ & معادله رگرسيون \\
\hline NPPjan & 75 & $0.0652 \mathrm{WMO}+0.0912 \mathrm{NINO} 1.2$ \\
\hline NPPfeb & 63 & 0.102 NINO4 \\
\hline NPPmar & 78 & $0.133 \mathrm{AAO}-0.839 \mathrm{AMO}-0.0752 \mathrm{NAO}+0.213 \mathrm{NINO} 1.2$ \\
\hline NPPapr & 55 & 2.68 NINO3.4 - 2.27 NINO4 \\
\hline NPPjul & 67 & -0.752 NINO3.4 + 1.08 NINO4 \\
\hline NPPaut & 84 & $0.223 \mathrm{SOI}-0.135 \mathrm{WMO}-0.271 \mathrm{NINO} 3+1.10 \mathrm{NINO} 4$ \\
\hline NPPoct & $-0.0678 \mathrm{SOI}$ & 35 \\
\hline NPPnov & 79 & 0.869 AMO -0.363 NINO1.2 -0.551 NINO3.4 + 0.915 NINO3 \\
\hline
\end{tabular}

جدول r. روابط رگرسيونى براى برآورد NPP در ماههاى مختلف در منطقه مورد مطالعه در روابط غيرهمزمان

\begin{tabular}{|c|c|c|}
\hline توليد خالص اوليه & $\mathrm{R}^{2}$ & معادله رگرسيون \\
\hline NPPmay & 83 & -0.153 AAOdec \\
\hline NPPjun & 68 & 0.0928 AOdec -0.196 AAOoct +0.262 WMOsep \\
\hline NPPsep & 79 & 0.117 NINO1.2jun +0.170 NINO1.2mar +0.147 WMOsep \\
\hline NPPdec & 54 & -0.0429 WMOaug -0.0309 SOImar \\
\hline
\end{tabular}
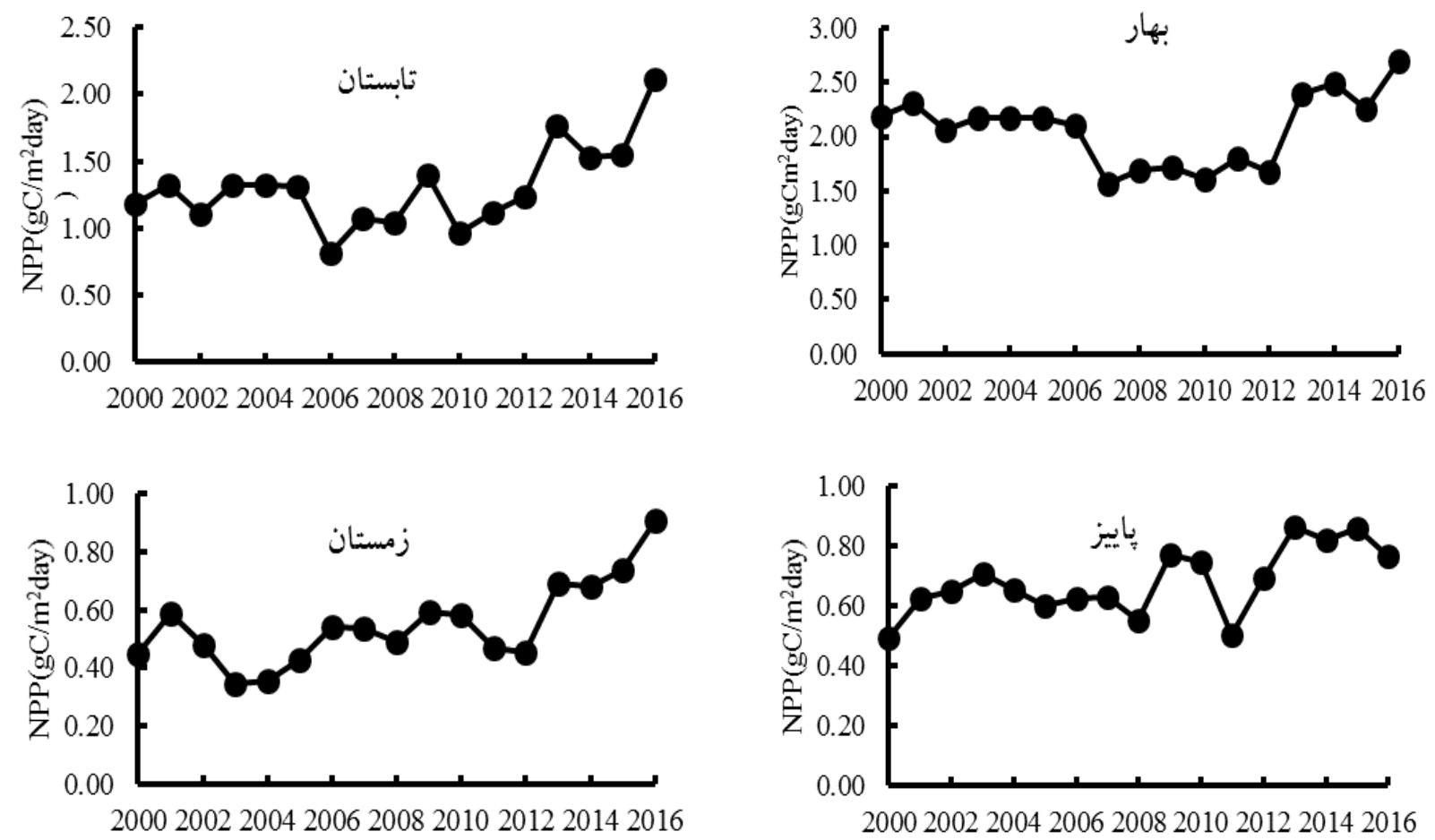

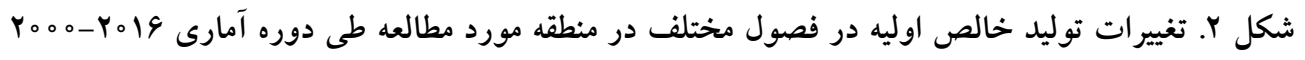

افزايشى داشته است. كمتــين ميـزان NPP، بـه مقــار NT/

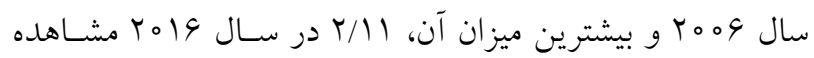

شد (شكل r). در اين فصل شـاخص نوسـان جنـوبى (SOI) و
فصل تابستان در طى دوره آمارى مورد مطالعه نشان داد كه بـهـ-

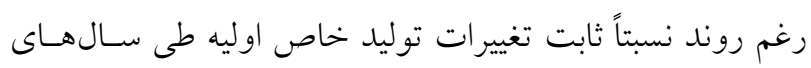

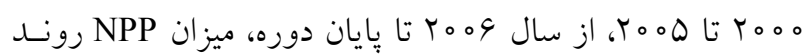


بومشناسى كاربردى / سال نهم / شماره سوم / باييز

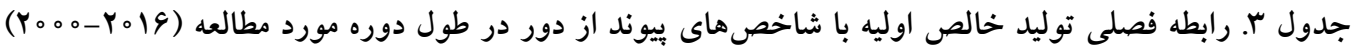

\begin{tabular}{|c|c|c|}
\hline توليد خالص اوليه & $\mathrm{R}^{2}$ & معادله رگرسيون \\
\hline 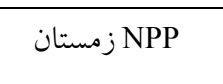 & 92 & $\begin{array}{c}-0.0662 \mathrm{AO}+0.110 \mathrm{AAO}-0.559 \mathrm{AMO}+0.0864 \mathrm{SOI}+0.164 \mathrm{WMO}+0.368 \\
\text { NINO1.2 }+0.768 \mathrm{NINO} 3.4-0.882 \text { NINO3 }\end{array}$ \\
\hline NPP بهار N & 45 & $0.3 \mathrm{NINO} 3.4$ \\
\hline N تابستان NPP & 58 & $0.266 \mathrm{SOI}+0.775 \mathrm{NINO} 4$ \\
\hline NPP & 71 & 0.784 AMO -0.237 NINO1.2 + 0.398 NINO3 -0.237 NINO4 \\
\hline
\end{tabular}

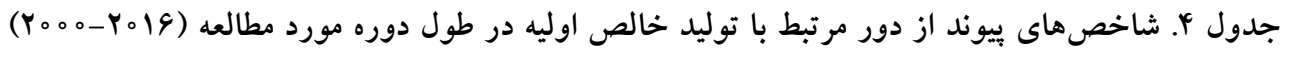

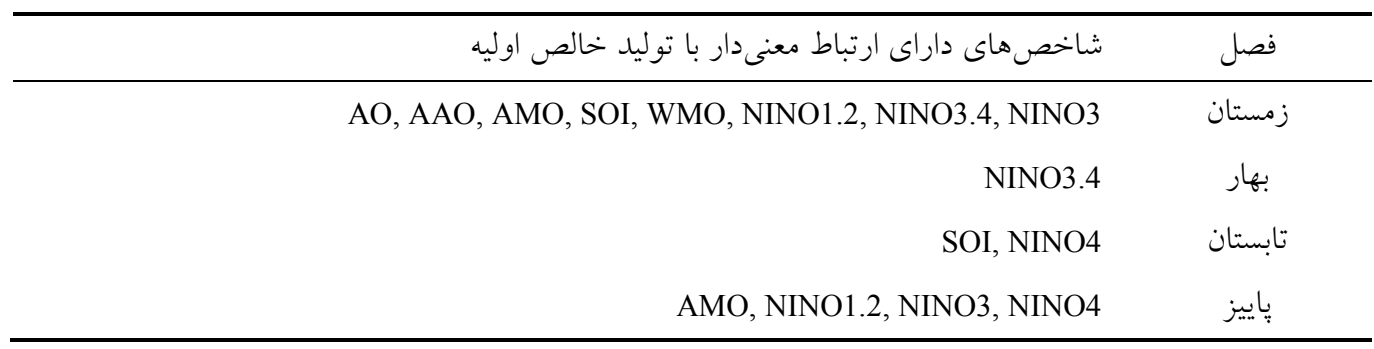

جنـوبى (SOI)، شـاخص نوسـان مديترانسه غربسى (WMO) و شاخص هاى NINO1.2 و NINO3.4 رابطه مثبت و معنسىدارى داشتند (جداول ب و †). بهطور كلسى در مجمـوع جهـار فصـل، ميانخين بيشترين ميزان توليد خالص اوليه در بيهنه مورد مطالعـه در فصل بهار به ميزان ب/ Y و كمترين آن در زمستان بـه ميـزان NPP هرم كربن در متر مربع در روز بهدست آمد. ميانكين توليدى در فصول تابستان و ياييز در يهنه مورد مطالعه هـم بـهـ-

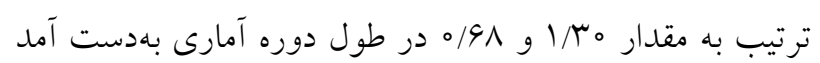

تغييرات توليد خالص اوليسه در كـل سـال و در طـول دوره آمارى مورد مطالعه در بيهنه مورد نظر، يس از يـكى رونـــ نسـبتاً

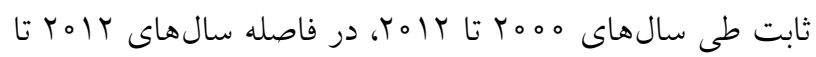
Yol9 يك روند محسوس افزايشى را نشان داد. ميانخين سـالانه توليد خالص اوليه در طول دوره آمارى مـورد مطالعسه در بهنـه مورد نظر به ميزان ها/ البهدست آمد. بـر ايسن اسـاس كمتـرين

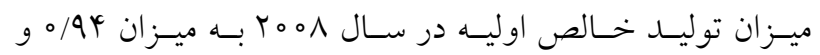

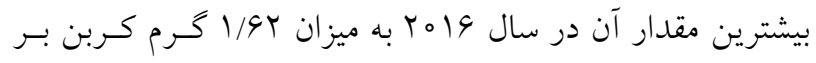
متر مربع در روز مشاهده شد. شـاخص NINO3 تنهـا شـاخص داراى ارتباط معنى دار با توليد خالص اوليه در اين دوره بود و
شاخص NINO4 رابطه مثبت و معنى دارى با توليد خالص اوليه داشتند (جداول بو ب). تغييرات توليد خـالص اوليسه در فصـل

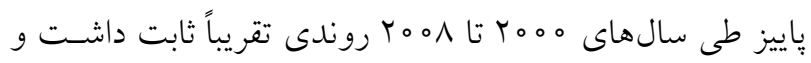

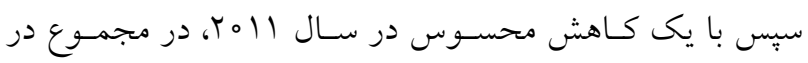
طى دوره مورد مطالعه روند افزايشى نشـان داد. كمتـرين ميـزان

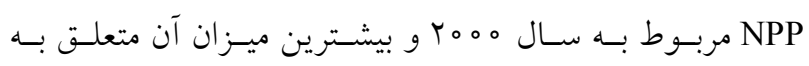

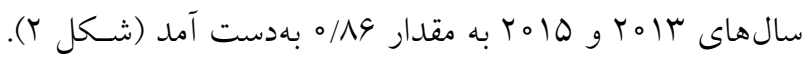
در اين فصل شـاخص هـاى AMO و NINO3 رابطـه معنسىدار افزايشى و شاخص هـاى NINO1.2 و NINO4 رابطـه معنسى دار منفى با توليد خالص اوليه نشان دادند (جداول با و †). در فصل زمستان كمترين ميزان NPP مربوط به سـال roه با مقدار بץ/ه گرم كربن در متر مربع در روز و بـالاترين ميـزان

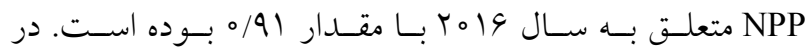
مجمـوع، تغييـرات NPP در طـول دوره آمـارى مــورد مطالعـه (Y०0०-Y०19) در اين فصل NPP با شاخص هاى نوسـان قطـب شـمال (AO)، شاخص دماى نيمروزى جند دههاى اقيانوس اطلـس (AMO) و شـاخص NINO3 رابطــه منفـى و معنـى دارى داشـتند و بــا شاخص هاى نوسـان قطـب جنـوب (AAO)، شـاخص نوسـان 


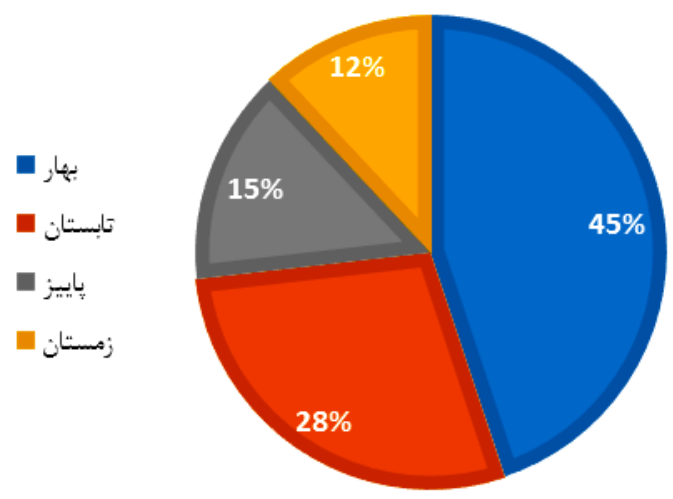

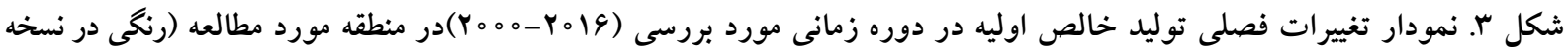
الكترونيكى)

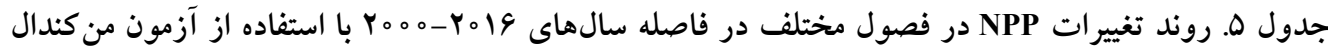

\begin{tabular}{|c|c|c|c|c|}
\hline ياييز & تابستان & بهار & زمستان & فصل \\
\hline$\Gamma / \Gamma Q^{*}$ & $1 / N r$ & سח/ס & T/VG:* & Z \\
\hline
\end{tabular}

روند تغييرات زمانى و مكانى توليد خالص اوليه و رابطـه آن بـا

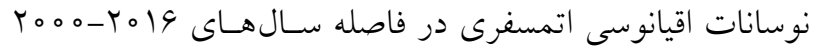

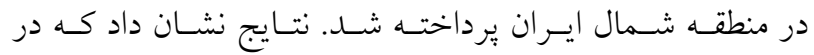
سالهاى اوليه بازه زمانى مورد مطالعه روند توليدات نسـبت بـه سالهاى انتهايى دوره كمتر بوده است. عليجانى و بابـايى (Y) و دوستان (91) در مطالعاتى كه بهمنظور تحليل خشكسـالى ايـران انجام دادند، به ترتيب بيان كردند كه در فاصله سالهاى هـ

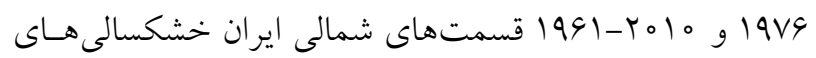
متفاوتى را تجربه كرده است. از طرف ديخر بـاز گير و همكـاران (^) در تحليل دادههاى دما و بارش در ايران بيان كردنـد كـهـ در

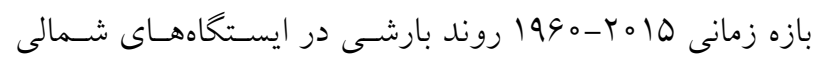
ايران افزايشى بوده است. روند تغييرات نشـان داد كـه NPP در فصول ياييز و زمستان در سـالهـاى مـورد مطالعـه افزايشسى و معنى دار بوده و در فصول بهار و تابستان روند معنىدارى نداشته است. اين مسئله ممكـن اسـت بـه افـزايش سـطح زيسر كشـت كياهانى مانند مركبات مربوط باشد كه در زمسـتان حالـت سـبز

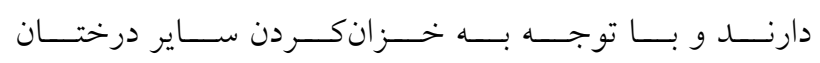

رابطه افزايشى با ميزان NPP نشان داد. با توجه به مقادير آزمون من كندال (جدول ه) مشــص شـــ تغييـرات ميـانخين فصـلى NPP در فصول زمستان و ياييز داراى روند افزايشى و معنسىدار

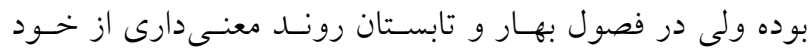
نشان نمى دهد. همجينين در شكل \& نقشـهــاى ميـانخين توليـد خالص اوليه در طول دوره آمارى مورد مطالعه نمايش داده شده كه نشاندهنده تغييرات مقدار NPP در فصول مختلف است.

\section{بحث و نتيجه گيرى}

تغييرات اقليمى نقش بسيار مهمى در يويايى و تغييرات بيوشـش

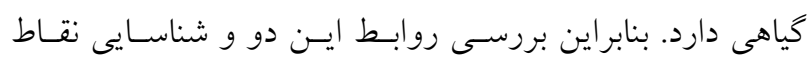

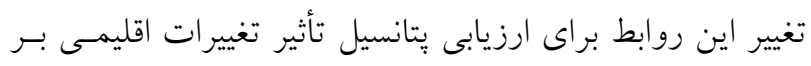

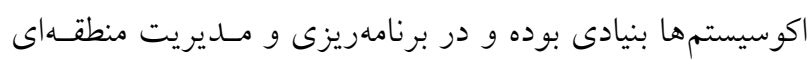
اراضى بسيار اهميـت دارد. نوسـانات اقليمسى از عوامـل مهـمـ و اصسلى تأثير خــذار بــر تغيــرات بوشـش كيـاهى اسـت كـهـ در درازمدت در صورت تداوم اين شـرايط باعـث ايجـاد تغييـرات زياد در بوشش گياهى مىشود (OY). در اين مطالعه بـهـ بررسى 

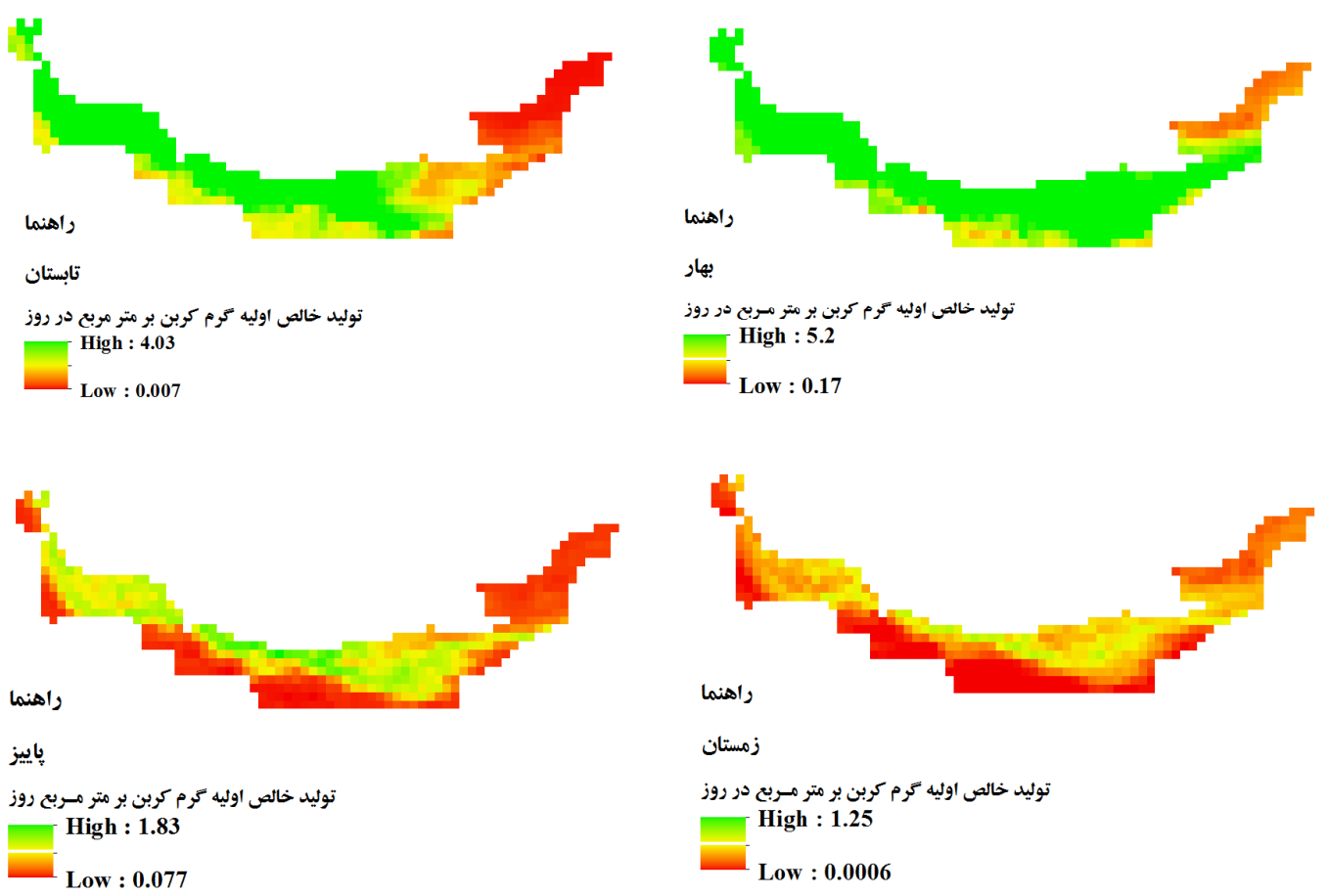

بهار

توليد خالص اوليد كرم كربين بر متر سمربع در روز

High : 5.2

Low : 0.17

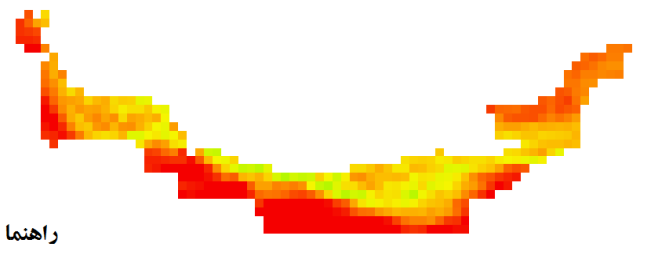

زمستان

توليد خالص اوليه كرم كربن بر متر مسربع در روز

High : 1.25

Low : 0.0006

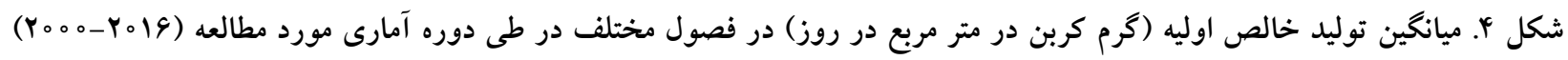
(رنخى در نسخه الكترونيكى)

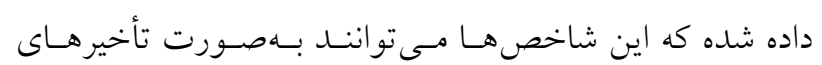

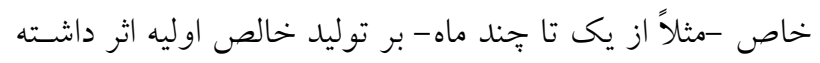

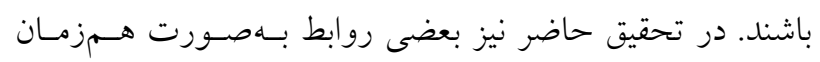

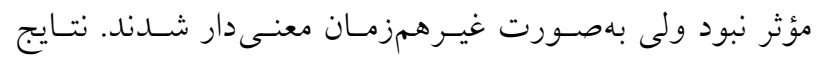

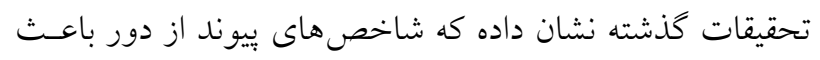

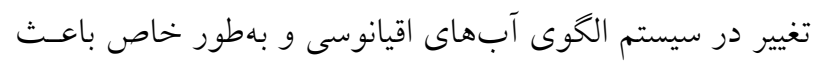

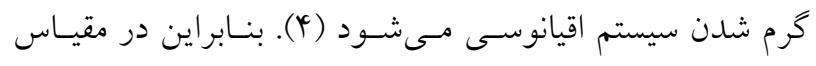

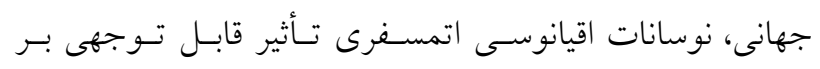

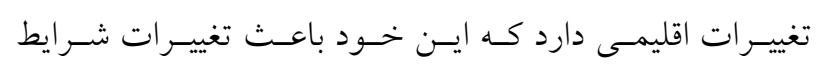

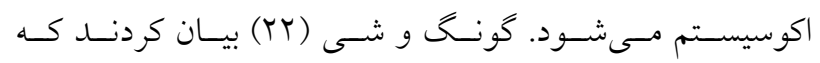

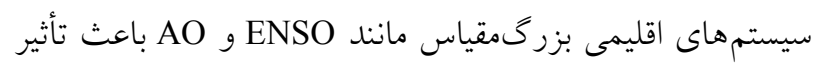

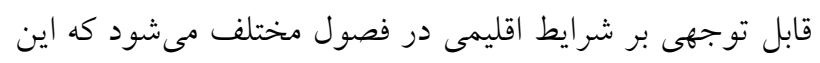

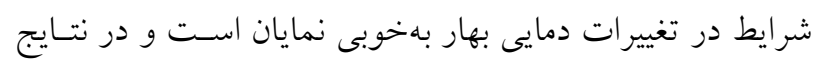

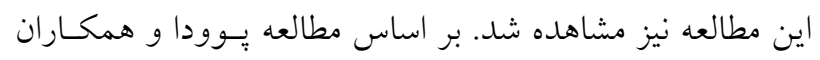

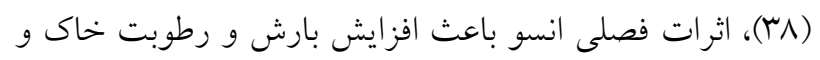

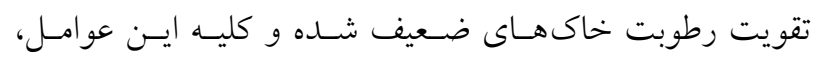

جنكلى در زمستان، حضور اين گياهان مىتواند باعـث افـزايش

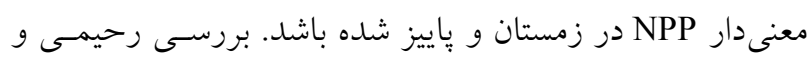

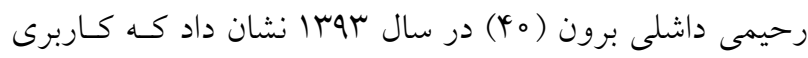

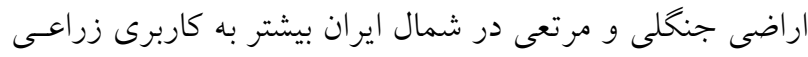

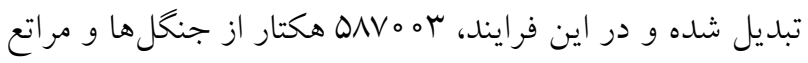

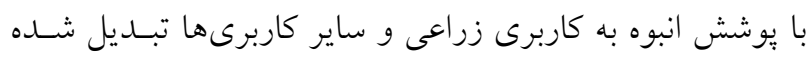

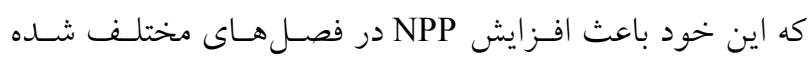

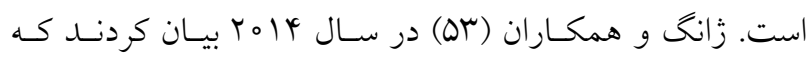

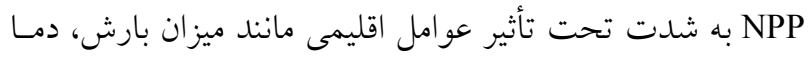

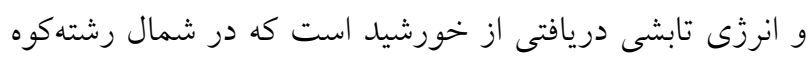

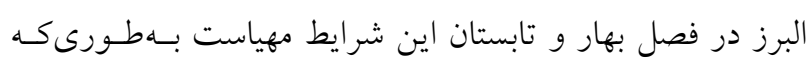

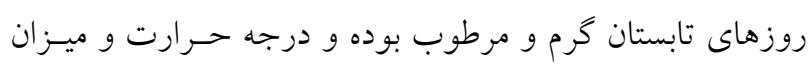

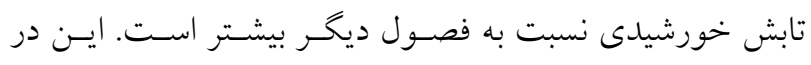

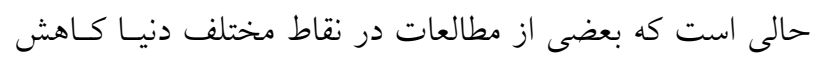

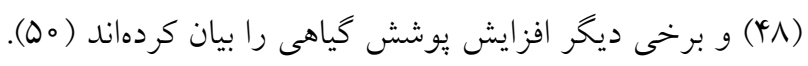

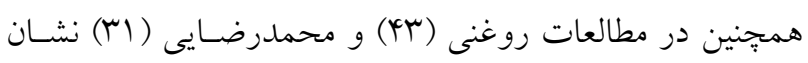




$$
\begin{aligned}
& \text { شرايط محيط را براى رشد كياه فراهم مى كند كه اين امر باعـث عرفت كه بهخوبى تأثير يذيرى توليدات گياهى را از پارامترهـاى }
\end{aligned}
$$

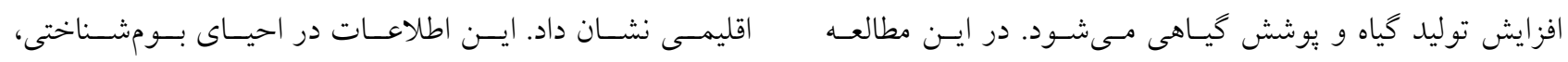

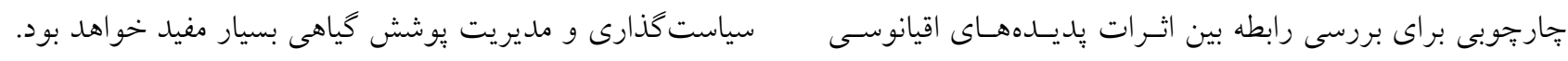

$$
\begin{aligned}
& \text { اتمسفرى و NPP در شمال رشته كوه البرز مـورد استفاده قـرار }
\end{aligned}
$$

\section{منابع مورد استفاده}

1. Abdi, A., A. Vrieling, G. Yengoh, A. Anyamba, J. Seaquist, C. Ummenhofer and J. Ardö. 2016. The El Niño -La Niña cycle and recent trends in supply and demand of net primary productivity in African drylands. Climatic Change 138: 111-125.

2. Alijani, B. and O. Babaei. 2009. Spatial analysis of short-term droughts in Iran. Geography and regional planning 109-121. (In Farsi)

3. Anyamba, A. and J. R. Eastman. 1996. Interannual variability of NDVI over Africa and its relation to El Niño/Southern Oscillation. Remote Sensing 17(13): 2533-2548.

4. Anyamba, A., C. J. Tucker, J. Compton and R. Mahoney. 2002. From El Niño to La Niña: vegetation response patterns over east and southern Africa during the 1997-2000 period. Journal of climate 15(21): 3096-3103.

5. Bala, G., J. Joshi, R. K. Chaturvedi, H. V. Gangamani, H. Hashimoto and R. Nemani. 2013. Trends and variability of AVHRR-derived NPP in India. Remote Sensing 5: 810-829.

6. Bao, G., A. Tuya, S. Bayarsaikhan, A. Dorjsuren, U. Mandakh, Y. Bao, C. Li and B. Vanchindorj. 2020. Variations and climate constraints of terrestrial net primary productivity over Mongolia. Quaternary International 537: 112125 .

7. Bastos, A., S. W. Running, C. Gouveia and R. M. Trigo. 2013. The global NPP dependence on ENSO: La Niña and the extraordinary year of 2011. Journal of Geophysical Research: Biogeosciences 118(3): 1247-1255.

8. Bazgir, S., F. Abbasi, E. Asadi Oskooei, M. Haghighat and P. Rezazadeh. 2019. Homogeneity analysis of temperature and precipitation with a climatic approach in Iran. Journal of Spatial Analysis Environmental hazards 1(6): 51-70. (In Farsi)

9. Brown, M. E., K. de Beurs and A. Vrieling. 2010. The response of African land surface phenology to large scale climate oscillations. Remote Sensing of Environment 114(10): 2286-2296.

10. Buermann, W., B. Anderson, C. J. Tucker, R. Dickinson, W. Lucht, C. Potter and R. B. Myneni. 2003. Interannual covariability in Northern Hemisphere air temperatures and greenness associated with El Niño-Southern Oscillation and the Arctic Oscillation. Journal of Geophysical Research: Atmospheres 108(D13): 1-16.

11. Cai, W., S. Borlace, M. Lengaigne, P. Van Rensch, M. Collins, G. Vecchi and L. Wu. 2014. Increasing frequency of extreme El Niño events due to greenhouse warming. Nature climate change 4(2): 111-116.

12. Cobb, K. M., N. Westphal, H. R. Sayani, J. T. Watson, E. Di Lorenzo, H. Cheng, R. L. Edwards and C. D. Charles. 2013. Highly variable El Niño-Southern Oscillation throughout the Holocene. Science 339(6115): 67-70.

13. Cramer, W., D. W. Kicklighter, A. Bondeau, B. Moore Iii, G. Churkina, B. Nemry and A. L. Schloss. 1999. Comparing global models of terrestrial net primary productivity (NPP): overview and key results. Global change biology 5(S1): 1-15.

14. Day, F. P. and C. D. Monk. 1977. Net primary production and phenology on a southern Appalachian watershed. American Journal of Botany 64(9): 1117-1125.

15. Dezfuli, A. K., M. Karamouz and S. H. Araghinejad. 2010. On the relationship of regional meteorological drought with SOI and NAO over southwest Iran. Theoretical and Applied Climatology 100: 57-66.

16. Doustan, R. 2015. Analysis of the Iran droughts in the past half century. Journal of Climate Research 6(23-24): 106107. (In Farsi)

17. Eisfelder, C., I. Klein, M. Niklaus and C. Kuenzer. 2014. Net primary productivity in Kazakhstan, its spatiotemporal patterns and relation to meteorological variables. Journal of Arid Environments 103: 17-30.

18. Gao, Y., X. Zhou, Q. Wang, C. Wang, Z. Zhan, L. Chen, J. Yan and R. Qu. 2013. Vegetation net primary productivity and its response to climate change during 2001-2008 in the Tibetan Plateau. Science of the Total Environment 444: 356-362.

19. Ghasemi, A. R. 2003. Meteorological drought in Iran and its association with the El Nino Southern Oscillation and Caspian Sea surface temperature. MSc Thesis, Shiraz University, Shiraz.

20. Ghasemi, A. R. and D. Khalili. 2006. The influence of the Arctic oscillation on winter temperature in Iran. 
Theoretical and Applied Climatology 85: 149-164.

21. Ghasemi, A. R. and D. Khalili. 2008. The association between regional and global atmospheric pattern and winter precipitation in Iran, Atmospheric Research 88: 116-133.

22. Gong, D. Y. and P. J. Shi. 2003. Northern hemispheric NDVI variations associated with large-scale climate indices in spring. International Journal of Remote Sensing 24(12): 2559-2566.

23. Hashimoto, H., R. R. Nemani, M. A. White, W. M. Jolly, S. C. Piper, C. D. Keeling, R. B. Myneni and S. W. Running. 2004. El Niño-Southern Oscillation-induced variability in terrestrial carbon cycling. Journal of Geophysical Research 109(D23110): 1-8.

24. Keeling, C. D., J. F. S. Chin and T. P. Whorf. 1996. Increased activity of northern vegetation inferred from atmospheric CO2 measurements. Nature 382(6587): 146-149.

25. Khatibi, R. 2016. Bioclimatic classification of Iran by multivariate statistical methods, PhD thesis. Isfahan University of Technology, Isfahan, Iran. (In Farsi)

26. Lehuger, S., B. Gabrielle, P. Cellier, B. Loubet, R. Roche, P. Béziat, E. Ceschiad and M. Wattenbach. 2010. Predicting the net carbon exchanges of crop rotations in Europe with an agro-ecosystem model. Agriculture, ecosystems \& environment 139(3): 384-395.

27. Li, J., S-P. Xie, E. R. Cook, M. S. Morales, D. Christie, N. Johnson, F. Chen, R. D. Arrigo, A. Flower, X. Gou and K. Fang. 2013. El Niño modulations over the past seven centuries. Nature Climate Change 3(9): 822-826.

28. Li, J., Y. Shi Yong and L. Liu. 2020. Determining the dominant factors determining the variability of terrestrial ecosystem productivity in China during the last two decades. Land Degradation \& Development 31(15): 2131-2145.

29. Lin, H., Q. Feng, T. Liang and J. Ren. 2013. Modelling global-scale potential grassland changes in spatio-temporal patterns to global climate change. International Journal of Sustainable Development \& World Ecology 20(1): 83-96.

30. McCabe, G. J., T. R. Ault, B. I. Cook, J. L. Betancourt and M. D. Schwartz. 2012. Influences of the El Niño Southern Oscillation and the Pacific Decadal Oscillation on the timing of the North American spring. International Journal of Climatology 32(15): 2301-2310.

31. Mohammadrezaei, M. 2017. Impact assessment of ocean-atmospheric indicators on drought in Iran, MSc Thesis. Isfahan University of Technology, Isfahan, Iran.

32. Nemani, R. R., C. D. Keeling, H. Hashimoto, W. M. Jolly, S. C. Piper, C. J. Tucker, R. B. Myneni and S. W. Running. 2003. Climate-driven increases in global terrestrial net primary production from 1982 to 1999. Science 300(5625): 1560-1563.

33. Osareh, M. J. and S. J. Seyed Akhlaghi. 2009. Strategic plan of research development in natural resources of Iran. Research Institute of Forests and Rangelands, Tehran, Iran. (In Farsi)

34. Peng, D., J. Huang, A. R. Huete, T. Yang, P. Gao, Y. Chen, H. Chen, J. Li and Z. Liu. 2010. Spatial and seasonal characterization of net primary productivity and climate variables in southeastern China using MODIS data. Journal of Zhejiang University SCIENCE B 11(4):275-285.

35. Piao, S., J. Fang and J. He. 2006. Variations in vegetation net primary production in the Qinghai-Xizang Plateau, China, from 1982 to 1999. Climatic Change 74(1): 253-267.

36. Potter, C., S. Klooster, R. Myneni, V. Genovese, P. N. Tan and V. Kumar. 2003a. Continental-scale comparisons of terrestrial carbon sinks estimated from satellite data and ecosystem modeling 1982-1998. Global and Planetary Change 39(3): 201-213.

37. Potter, C., S. Klooster, R. Myneni, V. Genovese, P. N. Tan and V. Kumar. 2003b. Continental-scale comparisons of terrestrial carbon sinks estimated from satellite data and ecosystem modeling 1982-1998. Global and Planetary Change 39(3-4): 201-213.

38. Poveda, G., A. Jaramillo, M. María Gil, N. Quiceno and R. Mantilla. 2001. Seasonally in ENSO-related precipitation, river discharges, soil moisture, and vegetation index in Colombia. Water Resources Research 37: 2169-2178.

39. Power, S., F. Delage, C. Chung, G. Kociuba and K. Keay. 2013. Robust twenty-first-century projections of El Niño and related precipitation variability. Nature 502(7472): 541-545.

40. Rahimi, D. and Y. Rahimi Dashliborun. 2016. Investigation of the effect of climate change and land use on floods in North of Iran. Geography and Environmental Planning 61(1): 89-101. (In Farsi).

41. Rezaei, S. R. 2009. Landscape of natural resources and watershesds of Iran. Research Institute of Forests and Rangelands, Tehran, Iran. (In Farsi).

42. Richardson, A. D., T. A., Black, P. Ciais, N. Delbart, M. A. Friedl, N. Gobron and S. Luyssaert. 2010. Influence of spring and autumn phenological transitions on forest ecosystem productivity. Philosophical Transactions of the Royal Society of London B, Biological Sciences 365(1555): 3227-3246.

43. Roghani, R. 2011. Investigating Iran's rainfall variations using ocean-atmospheric indices, MSc Thesis. Isfahan University of Technology, Isfahan, Iran. (In Farsi)

44. Roxburgh, S. H., S. L. Berry, T. N. Buckley, B. Barnes and M. L. Roderick. 2005. What is NPP? Inconsistent 
accounting of respiratory fluxes in the definition of net primary production. Functional Ecology 19(3): 378-382.

45. Vecchi, G. A., A. Clement and B. J. Soden. 2008. Examining the tropical Pacific's response to global warming. Eos 89(9): 81-83.

46. Vicente-Serrano, S. M., N. Delbart, T. Le Toan and M. Grippa. 2006. El Nino-Southern Oscillation influences on the interannual variability of leaf appearance dates in central Siberia. Geophysical Research Letters 33(3): 1-4.

47. Wang, B., H. H. Shugart and M. T. Lerdau. 2019. Complexities between plants and the atmosphere. Nature Geoscience 12(9): 693-694.

48. Wang, L., Y. Wei and Z. Niu. 2008. Spatial and temporal variations of vegetation in Qinghai Province based on satellite data. Journal of Geographical Sciences 18(1): 73-84.

49. Xu, K., L. He, H. Hu, Z. Wang, M. Lin, S. Liu, Y. Du, Y. Li and G. Wang. 2019. Indirect effects of water availability in driving and predicting productivity in the Gobi desert. Science of the Total Environment 697(133952): 1-8.

50. Xu, W., S. Gu, X. Zhao, J. Xiao, Y. Tang, J. Fang and S. Jiang. 2011. High positive correlation between soil temperature and NDVI from 1982 to 2006 in alpine meadow of the Three-River Source Region on the QinghaiTibetan Plateau. International Journal of Applied Earth Observation and Geoinformation 13(4): 528-535.

51. Yang, M., W. Zhu, Y. Pan, D. Yu and Z. Long. 2005. Spatio-temporal distribution of net primary productivity along the Northeast China transect and its response to climatic change from 1982 to 2000. In: Proceedings of IEEE International Geoscience and Remote Sensing Symposium. Seoul, South Korea. Volume 2, pp. 1318-1321.

52.Zhang, K., J. S. Kimball, K. C. McDonald, J. J. Cassano and S. W. Running. 2007. Impacts of large-scale oscillations on pan-Arctic terrestrial net primary production. Geophysical Research Letters 34(21): 1-5.

53. Zhang, Y., C. Song, K. Zhang, X. Cheng, L. E. Band and Q. Zhang. 2014. Effects of land use/land cover and climate changes on terrestrial net primary productivity in the Yangtze River Basin, China, from 2001 to 2010. Journal of Geophysical Research: Biogeosciences 119(6): 1092-1109.

54. Zhao, J., S. Huang, Q. Huang, H. Wang and G. Leng. 2018. Detecting the dominant cause of streamflow decline in the Loess Plateau of China based on the latest Budyko Equation. Water 10(9): 1-19. 


\title{
Investigating the Effects of Teleconnection Indices on Net Primary Production in the North of Iran's Alborz Mountains
}

\author{
S. M. Araghi Shahri ${ }^{1}$, S. Soltani ${ }^{1^{*}}$, M. Tarkesh ${ }^{1}$ and S. Pourmanafi ${ }^{2}$
}

(Received: February 18-2020; Accepted: August 23-2020)

\begin{abstract}
One of the main scientific topics on the effects of global climate change is to assess changes in the carbon cycle in rangelands. Net Primary Production (NPP) is an important component of this cycle, in terms of carbon storage, and a key indicator for assessing the ecosystem function. This research aimed to investigate the correlation between NPP and ocean-atmospheric oscillations, monthly and seasonally, from 2000 to 2016 in the north of Iran's Alborz Mountains. Net Primary Production of terrestrial vegetation was extracted from MODIS data and used in a model along with oceanatmospheric oscillations. Multivariate regression analysis was used to investigate the simultaneous and lagged status in different timescales. Mann-Kendal test was used for trend analysis in different seasons over the studied period. Results showed that the highest NPP values were 2.06 and $1.30 \mathrm{~g} \mathrm{C} \mathrm{m-2} \mathrm{d-1} \mathrm{in} \mathrm{spring} \mathrm{and} \mathrm{summer} \mathrm{and} \mathrm{the} \mathrm{lowest} \mathrm{were} 0.68$ and $0.55 \mathrm{~g} \mathrm{C} \mathrm{m-2} \mathrm{d-1} \mathrm{in} \mathrm{autumn} \mathrm{and} \mathrm{winter,} \mathrm{respectively.} \mathrm{The} \mathrm{trend} \mathrm{of} \mathrm{NPP} \mathrm{variations} \mathrm{was} \mathrm{significantly} \mathrm{different} \mathrm{in} \mathrm{autumn}$ and winter. Overall, it was showed that NPP was affected by climatic variables, especially precipitation, and variables related to ENSO indicator are the main factors affecting precipitation, thereby affecting NPP in the north of Iran.
\end{abstract}

Keywords: Ocean-Atmospheric Oscillations, Multivariate Regression, ENSO, Trend Analysis, Mann-Kendal, Remote Sensing

1. Department of Rangeland and watershed, Faculty of Natural Resources, Isfahan university of Technology, Esfahan, Iran.

2. Department of Environment, Faculty of Natural Resources, Isfahan university of Technology, Esfahan, Iran.

*: Corresponding Author, Email: ssoltani@cc.iut.ac.ir 